\title{
Endogenous CGRP protects against neointimal hyperplasia \\ following wire-induced vascular injury
}

Lei Yang ${ }^{1,2}$, Takayuki Sakurai ${ }^{1}$, Akiko Kamiyoshi ${ }^{1}$, Yuka Ichikawa-Shindo ${ }^{1}$, Hisaka Kawate ${ }^{1}$, Takahiro Yoshizawa ${ }^{1,3}$, Teruhide Koyama ${ }^{1,3}$, Yasuhiro Iesato ${ }^{1}$, Ryuichi Uetake ${ }^{1}$, Akihiro Yamauchi $^{1}$, Megumu Tanaka ${ }^{1}$, Yuichi Toriyama ${ }^{1}$, Kyoko Igarashi ${ }^{1}$, Takayuki Shindo ${ }^{1}$

${ }^{1}$ Department of Cardiovascular Research, Shinshu University Graduate School of Medicine

${ }^{2}$ Department of Epidemiology and Statistics, School of Public Health, Hebei Medical University

${ }^{3}$ Research Fellow of the Japan Society for the Promotion of Science

\section{Address for correspondence}

Takayuki Shindo, MD, PhD

Department of Cardiovascular Research,

Shinshu University Graduate School of Medicine

Asahi 3-1-1, Matsumoto, Nagano, 390-8621, Japan

Tel: +81-263-37-3192

Fax: +81-263-37-3437

Email: tshindo@shinshu-u.ac.jp 


\section{Abstract}

Neointimal hyperplasia is the primary lesion underlying atherosclerosis and restenosis after percutaneous coronary intervention. Calcitonin gene-related peptide (CGRP) is produced by alternative splicing of the primary transcript of the calcitonin/CGRP gene. Originally identified as a strongly vasodilatory neuropeptide, CGRP is now known to be a pleiotropic peptide widely distributed in various organs and tissues. Our aim was to investigate the possibility that CGRP acts as an endogenous vasoprotective molecule.

We compared the effect of CGRP deficiency on neointima formation after wire-induced vascular injury in wild-type and CGRP knockout (CGRP-/-) mice. We found that neointima formation after vascular injury was markedly enhanced in CGRP-/- mice, which also showed a higher degree of oxidative stress, as indicated by reduced expression of nitric oxide synthase, increased expression of p47phox, and elevated levels of 4HNE, as well as greater infiltration of macrophages. In addition, CGRP-deficiency led to increased vascular smooth muscle cell (VSMC) proliferation within the neointima. By contrast, bone marrow-derived cells had little or no effect on neointima formation in CGRP-/- mice. In vitro analysis showed CGRP-treatment suppressed VSMC proliferation, migration, and ERK1/2 activity.

These results clearly demonstrate that endogenous CGRP suppresses the oxidative stress and VSMC proliferation induced by vascular injury. As a vasoprotective molecule, CGRP could be an important therapeutic target in cardiovascular disease. 


\section{Key Words}

Calcitonin gene-related peptide (CGRP)

Neointimal hyperplasia

Vascular smooth muscle cell (VSMC)

Oxidative stress

Inflammation

\section{Highlights}

- In CGRP knockout mice, neointima formation after vascular injury is exacerbated.

- CGRP deficiency affects injury-induced proliferation of VSMCs rather than ECs.

- In CGRP knockout mice, oxidative stress and macrophage infiltration are increased.

- Bone marrow-derived cells do not contribute to the enhanced neointima formation.

- CGRP significantly suppresses VSMC proliferation and migration. 
Abbreviations

CGRP: Calcitonin gene-related peptide

VSMC: Vascular smooth muscle cell

EC: Endothelial cell

ROS: Reactive oxygen species

AM: Adrenomedullin

BMT: Bone marrow transplantation 


\section{Introduction}

Neointimal hyperplasia is the primary lesion underlying atherosclerosis and restenosis after percutaneous coronary intervention[1]. Accumulating evidence now shows that inflammatory cell infiltration[2, 3], proliferation/migration of vascular smooth muscle cells (VSMCs)[4, 5], and deposition of extracellular matrix[6] all contribute to the pathogenesis of neointimal hyperplasia. Moreover, inflammatory cell infiltration of the neointima is intimately related to oxidative stress[7], and several lines of evidence indicate that NADPH oxidase plays a crucial role in the production of reactive oxygen species (ROS) within the neointima[8, 9].

Calcitonin gene-related peptide (CGRP) is a 37-amino acid peptide produced by alternative splicing of the primary transcript of the calcitonin/CGRP gene[10]. CGRP is widely distributed in the central and peripheral nervous systems and has been shown to exert a variety of effects within the cardiovascular system[11], including vasodilation, protection of endothelial cell function, and inhibition of VSMC proliferation[12-14]. CGRP also has pleiotropic functions that have been implicated in the regulation of cell proliferation[15] and differentiation[16]. The potent microvascular vasodilatory action of CGRP and its wide distribution in the periphery ensure that it is in a prime position to protect tissues from injury in several disease models[17, 18], and to play a variety of roles under normal physiological conditions[19, 20]. 
Based on its structural homology and similar vasodilatory effects, CGRP has been classified as an adrenomedullin (AM) family peptide. Endogenous AM has been shown to exert a protective effect during the vascular response to injury[21]. For example, AM inhibits angiotensin II-induced proliferation and migration of VSMCs[22], possibly by inhibiting ROS production. Like AM, CGRP inhibits angiotensin II-induced VSMC proliferation through inactivation of the extracellular signal-regulated protein kinase $1 / 2$ (ERK1/2) signaling pathway[23] and inhibits hypoxia-induced proliferation of pulmonary artery SMCs via the ERK1/2/p27/c-fos/c-myc pathway ${ }^{14}$.

To investigate the possibility that CGRP serves as an endogenous vasoprotective substance, in the present study we used CGRP knockout (CGRP-/-) mice for assessing the effect of CGRP deficiency on neointima formation after vascular injury. We then tested whether inflammatory cell infiltration and ROS are involved in the development of neointimal hyperplasia, and because bone marrow-derived cells reportedly contribute to neointima formation[24], we also tested a bone marrow transplantation (BMT) model using CGRP-/- mice. Finally, we investigated the effects of CGRP on the proliferation and migration of VSMCs. 


\section{Materials and methods}

\subsection{Animals}

We generated CGRP knockout mice using a targeting DNA construct that replaced exon 5 encoding a CGRP-specific region[25]. C57BL/6 pure background mice were used for bone marrow transplantation (BMT) experiments. In other experiments, $129 / \mathrm{Sv}$ x C57BL/6 hybrid background mice were used. Male CGRP-/- mice and their wild-type (WT) littermates mice were maintained under specific pathogen-free conditions in an environmentally controlled clean room at the Division of Laboratory Animal Research, Department of Life Science, Research Center for Human and Environmental Sciences, Shinshu University. All animal experiments were conducted in accordance with the ethical guidelines of Shinshu University.

\subsection{Wire-induced vascular injury}

Wire-induced vascular injury of the right femoral artery was produced as described previously by Sata et al[26]. We confirmed that this procedure induced reproducible neointima formation in 12- to 16-week-old 129/Sv x C57BL/6 mice. Some CGRP-/- mice underwent isolation of the femoral artery without wire-injury (sham-operated group).

\subsection{Histology and immunohistochemistry}


The femoral arteries were excised from each mouse, fixed in $4 \%$ paraformaldehyde for $24 \mathrm{~h}$ and embedded in paraffin. The arteries were then cut into 5- $\mu \mathrm{m}$ sections, which were stained with hematoxylin-eosin (HE) and Elastica Van Gieson (EVG). For immunohistochemical analysis, arterial sections were incubated with rat anti-mouse CD31 (BD Pharmingen, San Jose, CA), mouse anti-human $\alpha$-smooth muscle actin (Dako), rat anti-mouse F4/80 (Serotec), rat anti-mouse 4-Hydroxy-2-nonenal (4HNE) (NOF Corporation), rabbit anti-rat p67-phox (Upstate), mouse anti-rat PCNA (Dako), or mouse IgG2a (negative control) (Dako). DAPI (Invitrogen) was used to stain the nuclei.

For the evaluation of re-endothelialization after the wire-injury, endothelial cells (ECs) were identified by immunostaining with anti-CD31 antibody. The percentage of CD31-positive length to lumen perimeter in the femoral section was evaluated.

Representative 1 section from 6 cross-sections from each mouse was used to calculate the percentage.

\subsection{RNA extraction and quantitative real-time RT-PCR}

Total RNA was extracted from tissues or cells using TRIZOL Reagent (Invitrogen, Carlsbad, CA), after which the sample was treated with DNA-Free (Ambion, Austin, TX) to remove contaminating DNA, and subjected to reverse transcription using a High Capacity cDNA Reverse Transcription Kit (Applied Biosystems, Carlbad, CA). Semiquantitative 
RT-PCR was then carried out using Ex Taq DNA polymerase (Takara, Japan). Quantitative real-time RT-PCR was carried out using an Applied Biosystems 7300 real time PCR System (Applied Biosystems) with SYBR green (Toyobo, Japan) or Realtime PCR Master Mix (Toyobo) and TaqMan probe (MBL). Values were normalized to mouse GAPDH (Pre-Developed TaqMan ${ }^{\circledR}$ assay reagents, Applied Biosystems). Primers and probes are listed in Table.1

\subsection{Bone marrow transplantation}

BMT model mice were produced as described previously[27]. For the study of BMT model mice, C57BL/6 pure background mice were generated by speed congenic method. Whole bone marrow cells were harvested from WT and CGRP-/- mice by flushing their femurs with PBS. Red blood cells were lysed by incubation in ACK buffer $(150 \mathrm{mmol} / \mathrm{L}$ $\mathrm{NH} 4 \mathrm{Cl}, 10 \mathrm{mmol} / \mathrm{L} \mathrm{KHCO} 3,0.1 \mathrm{mmol} / \mathrm{L} \mathrm{EDTA}, \mathrm{pH} 7.2$ ) for $20 \mathrm{~min}$ at $0^{\circ} \mathrm{C}$. The remaining cells were washed 3 times with PBS and resuspended in $1 \mathrm{~mL}$ of PBS. Recipient mice (C57BL/6 background; purchased from Charles River Laboratories Japan, Inc.; male, 7 to 8 weeks old) were lethally irradiated with a total dose of 9 Gy (MBR-155R2, Hitachi, Japan) and injected with bone marrow cells via the tail vein. Using this protocol, we produced 2 types of BMT mice: WT to WT $\left(\mathrm{BMT}^{\mathrm{WT} \rightarrow \mathrm{WT}}\right)$ and CGRP-/- to WT $\left(\mathrm{BMT}^{\mathrm{CGRP}-/-\mathrm{WT}}\right)$. After 8 weeks, all BMT mice underwent wire-induced vascular injury as described previously[27]. 


\subsection{Cell culture}

Macrophages: WT and CGRP-/- mice were intraperitoneally injected with $2 \mathrm{ml}$ of $3 \%$ thioglycolate medium (DIFCO) (Biobrás, Montes Claros, Brazil). After 3 days, macrophages were harvested by peritoneal lavage using cold PBS. The cells were counted, centrifuged and resuspended at a concentration of $1 \times 10^{6} / \mathrm{mL}$ in RPMI 1640 (Invitrogen) medium containing 10\% fetal bovine serum (FBS) (Equitech-Bio Inc, Kerrville, TX) and a mixture of $100 \mathrm{U} / \mathrm{ml}$ penicillin-100 $\mu \mathrm{g} / \mathrm{ml}$ streptomycin (Invitrogen). The macrophage suspension was added to $60 \mathrm{~mm}$ dishes and incubated for $2 \mathrm{~h}$ at $37^{\circ} \mathrm{C}$ under a $5 \% \mathrm{CO}_{2}$ atmosphere. The medium was then removed, and the dishes were washed twice with PBS before addition of $3 \mathrm{ml}$ of warm $\left(37^{\circ} \mathrm{C}\right)$ RPMI 1640 (Invitrogen) medium containing $10 \%$ FBS (Equitech-Bio Inc, Kerrville, TX) and a mixture of $100 \mathrm{U} / \mathrm{ml}$ penicillin-100 $\mu \mathrm{g} / \mathrm{ml}$ streptomycin (Invitrogen). The plates were then incubated for $72 \mathrm{~h}$ at $37^{\circ} \mathrm{C}$ under a $5 \% \mathrm{CO}_{2}$ atmosphere, after which the macrophages were collected and analyzed by quantitative real-time RT-PCR.

VSMCs: Rat VSMCs were purchased from Lonza (Lonza Walkersville, Inc, USA) and cultured in DMEM:F12 (Invitrogen) supplemented with 20\% FBS (Equitech-Bio Inc, Kerrville, TX) and a mixture of $100 \mathrm{U} / \mathrm{ml}$ penicillin-100 $\mu \mathrm{g} / \mathrm{ml}$ streptomycin (Invitrogen), according to the supplier's protocol. Mouse VSMCs were isolated from the aorta of 6- to 
8-week-old WT and CGRP-/-mice. In brief, the tunica media was separated from the

adventitia and endothelium and cultured in Dulbecco's modified eagle medium (DMEM)

(Invitrogen) supplemented with 10\% fetal bovine serum (FBS) (Equitech-Bio Inc, Kerrville,

TX) and a mixture of $100 \mathrm{U} / \mathrm{ml}$ penicillin-100 $\mu \mathrm{g} / \mathrm{ml}$ streptomycin (Invitrogen) [28, 29].

Rat or mouse VSMCs with 3 to 10 passages were used in the experiments. Each individual experiment was repeated at least 3 times with different cell preparations.

\subsection{Proliferation assay}

VSMCs $\left(1 \times 10^{5}\right)$ were cultured in 96-well plates, incubated in DMEM: F12

(Invitrogen) without serum for $16 \mathrm{~h}$ and then with treated with human CGRP $\left(10^{-10}-10^{-6} \mathrm{M}\right)$

(Peptide Institute Inc., Osaka, Japan), in the absence or presence of PDGF-BB (10ng/ml)

(Pepro-Tech, Inc) for $6 \mathrm{~h}, 12 \mathrm{~h}$ and $24 \mathrm{~h}$. VSMCs proliferation was then measured based on uptake of 5-bromo-2' -deoxyuridine (BrdU) using a Cell Proliferation ELISA kit (Roche Diagnostics, Mannheim, Germany) according to the manufacturer's specifications.

\subsection{Scratch-Wound assay}

For scratch assays, rat VSMCs were seeded in fibronectin-coated plates. Cells were grown to subconfluence (80\%) in DMEM:F12 supplemented with 20\% FBS and a mixture of $100 \mathrm{U} / \mathrm{ml}$ penicillin-100 $\mu \mathrm{g} / \mathrm{ml}$ streptomycin. To synchronize the cells, the medium was 
replaced with serum-free medium. After 16h, a scratch was made in each well, and the culture was continued in $20 \% \mathrm{FBS}+$ medium with the absence or presence of CGRP or PDGF-BB. Five fields were then randomly selected in each plate, and gap areas were recorded immediately after scratching and $12 \mathrm{~h}$ later, so that cell migration during the $12 \mathrm{~h}$ interval could be calculated.

\subsection{Western blotting}

VSMCs was lysed in ice-cold RIPA Lysis Buffer System (Santa Cruz) supplemented with PosSTOP phosphatase inhibitor (Roche Applied Science) and then sonicated. Samples of the resultant lysate were subjected to SDS-PAGE, and the resolved proteins were transferred to cellulose nitrate membranes (GE Healthcare). After blocking in 5\% skim milk, the membranes were incubated with primary antibodies against ERK1/2 (Cell Signaling) and phospho-ERK1/2 (EPITOMICS) followed by appropriate secondary antibodies (Santa Cruz). The bound antibodies were visualized using chemiluminescent HRP substrate (MILLIPORE), and the chemiluminescence was analyzed using an Image Quant LAS 4000 system (GE Healthcare). Levels of ERK1/2 activation were determined based on the ratios of the band intensities after blotting with antibodies specific for the phosphorylated and unphosphorylated proteins. For quantification, western blot images were captured and analyzed using Scion Image. 


\subsection{Statistical analysis}

Values are expressed as means \pm SE. Student's t test was used to determine significant differences between 2 groups. One-way ANOVA followed by Fisher's PLSD was used to determine significant differences between 3 or more groups. All analyses were performed using BZ-II analyzer software (Keyence). Values of $p<0.05$ were considered significant. 


\section{Results}

3.1 Changes in the gene expression of CGRP receptor components (CLR and RAMP1) following wire-induced vascular injury

We initially used real-time PCR to analyze the expression of the CGRP receptor (CLR) and its receptor activity-modifying protein (RAMP1) in sham-operated (Sham) and wire-injured (Injury) arteries from WT and CGRP-/- mice. We found that expression of both CLR and RAMP1 tended to be lower in CGRP-/- than WT mice, and that the expression was downregulated by wire-induced injury in arteries from both genotypes. Among these changes, the expression of CLR in wire-injured arteries from CGRP-/-mice was significantly lower than that in sham-operated CGRP-/- mice (Figure 1A).

\subsection{Effect of CGRP deficiency on neointima formation}

We then investigated whether CGRP-deficiency influences neointima formation after wire-induced vascular injury. EVG staining showed marked neointima formation in CGRP-/- mice 28 days after vascular injury (Figure 1B). Quantitative analysis showed that the neointimal area, medial area and intima/media $(\mathrm{I} / \mathrm{M})$ ratio were all significantly increased in CGRP-/- mice (Figure 1C-E).

CGRP-/- mice were previously shown to have slightly elevated blood pressure, so we assessed the effect of blood pressure in the enhanced neointima formation in CGRP-/-. An 
antihypertensive agent, hydralazine, was used to decrease the blood pressure, however, the neointimal formation was not significantly reduced in CGRP-/- mice (Supplementary Figure 1A, B). This result suggests that blood pressure appears not to be a potential cause of the enhanced neointimal formation in CGRP-/- mice. We also confirmed the enhanced neointimal formation in CGRP-/- mice in a cuff-injury model (Supplementary Figure 2A, B).

\subsection{Evaluation of endothelial cells (ECs) and VSMCs in the wire-injured arteries}

CGRP and its receptor system are present on both vascular ECs and VSMCs[30].

Because early re-endothelialization after vascular injury is known to attenuate neointima formation[27], we assessed re-endothelialization by immunostaining for the EC marker CD31. However, we found no significant difference in re-endothelialization between WT and CGRP-/- mice (Figure 1F and 1G). In similar fashion, we also immunostained for $\alpha$-smooth muscle actin ( $\alpha$-SMA) to detect VSMCs and assess their presence within the neointima.

Consistent with earlier reports[26, 31], neointimal lesions contained large numbers of VSMCs (Figure 1H). In the neointima, $\alpha$-SMA-positive area was increased more in CGRP-/- mice than WT mice (Figure 1I). These data suggest CGRP-deficiency influences the proliferation of VSMCs than ECs after vascular injury.

\subsection{Evaluation of macrophages}


Inflammatory reactions are thought to be deeply involved in the progression of

atherosclerosis. We therefore assessed the roles of inflammatory cytokines and macrophages. Real-time PCR analysis revealed that the F4/80, CCR2 and CCR2/CD68 ratio (i.e., M1 macrophage marker/general macrophage marker) were significantly increased in CGRP-/- mice at 28 days after vascular injury. In addition, expression of the inflammatory cytokines TNF- $\alpha$ and TGF $\beta 1$ tended to be higher in CGRP-/- mice than WT mice (Figure 2A). When we immunostained for F4/80 to detect the presence of macrophages (Figure 2B), we found that the numbers of macrophages in neointimal and adventitial areas were both significantly higher in CGRP-/- than in WT mice at 28 days after vascular injury (Figure 2C and 2D). On the other hand, there was no significant difference in sham-operated mice or 14 days after injury by analysis of relative gene expression or immunostaining (Figure 2A, 2B).

We next collected peritoneal macrophages from WT and CGRP-/- mice and assessed the expression of CGRP and its receptor genes, CLR and RAMP1. Little CGRP was detected in macrophages from either group, and expression of CLR and RAMP1 did not differ between WT and CGRP-/- macrophages. We also found that expression of interleukin (IL)-1 $\beta$ tended to be higher in CGRP-/- than WT macrophages, but the difference was not statistically significant; moreover, the expression of IL-6, TNF- $\alpha$ and MCP-1 did not differ between CGRP-/- and WT macrophages (Figure 2E). These data suggest that the inflammatory 
response within the neointima following wire injury is exacerbated in CGRP-/- mice, but a CGRP-deficiency in the inflammatory cells themselves does not appears to be the primary cause of the enhanced neointima formation seen in CGRP-/- mice.

\subsection{Evaluation of neointimal oxidative stress}

Oxidative stress is strongly associated with vascular lesions. To assess its role in neointima formation, we analyzed the expression of oxidative stress-related genes following wire-induced vascular injury. We found slight upregulation in NADPH oxidase subunit genes in CGRP-/- mice without injury (Sham in Figure 3A). After injury, we found that expression of p47phox, a cytosolic component of NADPH oxidase, was significantly increased, while expression of endothelial nitric oxide (NO) synthase (eNOS) was significantly reduced in CGRP-/- mice (Injury in Figure 3A). (For a more detailed time course, please refer to Supplementary Figure 3). Immunostaining of 4-hydroxy-2-nonenal (4HNE), a product of lipid peroxidation, was slightly increased in CGRP-/- even without injury (Sham in Figure 3B) and it was increased to a greater degree in wire-injured arteries from CGRP-/- mice than WT mice, particularly in the adventitia (Injury in Figure 3B). Immunostaining of p67phox was also increased in the wire-injured arteries of CGRP-/- mice. It appears from these results that the level of oxidative stress in the vascular lesions is higher in CGRP-/- than WT mice. 


\subsection{Cell proliferation within neointimal lesions}

Neointimal lesions after vascular injury are mainly comprised of proliferating VSMCs.

We estimated the level of their proliferative activity in vivo by immunostaining for PCNA.

The number of PCNA-positive cells was significantly higher in neointimal lesions in

CGRP-/- mice than WT mice (Figure 4), indicating a higher level of cell proliferation within the vascular lesions in CGRP-/- mice.

\subsection{Role of bone marrow cell-derived CGRP in neointima formation}

Next, to assess the role of CGRP-deficient bone marrow in the enhanced neointima formation seen in CGRP-/- mice, we generated two types of BMT mice $\left(\mathrm{BMT}^{\mathrm{WT} \rightarrow \mathrm{WT}}\right.$, $\mathrm{BMT}^{\mathrm{CGRP}-/-\rightarrow \mathrm{WT}}$ ) and evaluated neointima formation following wire-induced injury. Quantitative analysis showed that the neointimal area, medial area and intima/media (I/M) ratio did not differ between the two transplant groups (Figure 5A-D), indicating that bone marrow-derived cells did not contribute substantively to the enhanced neointima formation observed in CGRP-/- mice.

\subsection{Effects of CGRP on VSMC proliferation and migration}

Finally, we analyzed the effects of CGRP on VSMCs in vitro. First, using BrdU 
uptake as an index, we evaluated proliferation activity of cultured VSMCs. CGRP

significantly decreased the proliferation of rat VSMCs stimulated by PDGF-BB in a dose(Figure 6A) and time-dependent (Figure 6B) manner. We then evaluated the migration and proliferation of the VSMCs using scratching assay. We also found that CGRP administration significantly decreased the migration and proliferation of rat VSMCs (Figure 6C). We also confirmed the effect of CGRP using VSMCs, which were primarily cultured from mice. CGRP administration also decreased the proliferation of mouse VSMCs (Figure 6D). On the other hand, the cellular proliferation was enhanced in VSMCs isolated from CGRP-/- (Figure 6E).

Western blot analysis revealed $1 \mathrm{~h}$ CGRP-treatment $\left(10^{-9}-10^{-7} \mathrm{M}\right)$ significantly suppressed the ERK1/2 activation level in the rat VSMCs (Figure 6F). 


\section{Discussion}

Our findings in this study are as follows: (1) Neointima formation after vascular injury is significantly enhanced by CGRP deficiency. (2) CGRP deficiency most likely affects injury-induced proliferation of VSMCs rather than ECs. (3) Oxidative stress and macrophage infiltration are increased by CGRP deficiency. (4) Bone marrow-derived cells do not meaningfully contribute to the enhanced neointima formation observed in CGRP-deficient mice. (5) CGRP significantly suppresses VSMC proliferation migration, and ERK1/2 activation level.

CGRP reportedly exerts protective effects in several organ systems. For instance, CGRP deficiency makes the heart and kidneys more vulnerable to hypertension-induced damage[17]; CGRP plays an important role in mediating the protective effects observed with ischemic preconditioning in the heart[32]; and endogenous CGRP exerts a protective effect against hepatic injury[33]. In the present study, we demonstrated that CGRP-deficiency leads to enhanced neointima formation at 28 days after vascular injury, suggesting endogenous CGRP plays a key role in vascular homeostasis and inhibits the progression of atherosclerosis.

Macrophages and inflammatory mediators stimulate VSMC proliferation and neointimal hyperplasia. Earlier studies showed that CGRP inhibits infiltration by macrophages and other inflammatory cells, as well as the expression of inflammatory mediators[34, 35]. 
Zhang et al reported that transfection of CGRP inhibited expression of inflammatory mediators, macrophage infiltration, and neointimal hyperplasia in experimental vein graft disease[36]. However, in the present study, we found no significant changes in the expression of inflammatory cytokines by CGRP-/- macrophages, as compared to WT cells. This suggests CGRP-deficient macrophages do not directly activate innate immunity. More likely, it is CGRP-deficient vascular component cells that contribute to the exacerbation of vascular lesions in CGRP-/- mice. Consistent with that idea, our results indicate that bone marrow-derived cells do not meaningfully contribute to the enhanced neointima formation observed in CGRP-/- mice. Although recent reports suggest bone marrow cells participate in neointima formation after vascular injury[24, 31, 37], our findings with BMT mice indicate the main contributors to the neointimal hyperplasia seen in CGRP-/- mice arise from the local enviroment within the injured artery. BMT experiment in our study showed reduced neointimal and medial hypertrophy compared with other experiments without BMT. As reported, BMT procedure with irradiation may itself result in reduced hypertrophy [37]. Another explanation is that we used C57BL/6 background mice in the BMT study. It was reported that C57BL6/J background mice showed reduced neointimal formation compared with other background mice in the wire-injury model [26]

PCNA is a reliable indicator of the cellular proliferation status[38], while ERK1/2 is an important kinase in an intracellular signaling pathway crucially involved in regulating VSMC 
proliferation[39, 40]. Our immunohistochemical analysis of PCNA showed VSMC proliferation to be enhanced within vascular lesions in CGRP-/- mice, which suggests CGRP-deficiency enhances proliferation of VSMCs rather than ECs following vascular injury. To determine cell proliferation activity in vitro, we analyzed the effects of CGRP on cultured rat and mouse VSMCs. Conversely, application of exogenous CGRP suppresses VSMC proliferation and migration. We also found exogenous CGRP suppressed ERK1/2 activation, which may explain the suppressive effects of CGRP on the cellular proliferation and migration.

Several lines of evidence suggest that ROS play a crucial role in neointima formation[8, 9]. Major sources of ROS are thought to be eNOS-uncoupling and NADPH oxidase[41] CGRP has been shown to activate eNOS via the cAMP-PKA[42] and AMPK[43] pathways. In the present study, we found that the expression of a NADPH subunit, p47phox, was increased while expression of eNOS was reduced in wire-injured arteries from CGRP-/- mice. At the same time, levels of $4 \mathrm{HNE}$, a lipid peroxidation product, were also increased, predominantly in the adventitia of the injured arteries. Kawai et al. proposed the plausible hypothesis that in response to vascular injury, ROS are produced by inflammatory cells present in the adventitia[21]. We also found that macrophage numbers were predominantly increased in the adventitia of wire-injured arteries. Thus increased ROS production could significantly contribute the enhanced neointima formation seen in CGRP-/- mice. 
The effect of CGRP on vascular component cells appears to vary among species and vessel types. In rat aorta[44] and pulmonary artery[45], CGRP interacts with endothelial receptors, stimulating the release of endothelium-derived relaxing factors. By contrast, in cat cerebral[46], pig coronary[47] and rat mesenteric vessels[48], CGRP acts directly on VSMCs. Recently, Zhou et al reported that CGRP inhibits angiotensin II-induced endothelial progenitor cell senescence by upregulating klotho expression[49]. Other investigators also showed that re-endothelialization (e.g., vascular repair) by bone marrow-derived endothelial progenitor cells is an important determinant affecting neointima formation after vascular injury[27, 50, 51]. However, we observed that CGRP-deficiency primarily enhanced the proliferation of VSMCs and had no effect on re-endothelialization after vascular injury.

\section{Conclusion}

In summary, CGRP-/- mice showed marked neointimal hyperplasia in wire-injured arteries with concomitant increases in VSMC proliferation and oxidative stress. We suggest that endogenous CGRP may counteract the ROS generation and VSMC proliferation induced by vascular injury, and that CGRP could be an important therapeutic target in vascular diseases such as atherosclerosis and restenosis after percutaneous coronary intervention. 


\section{Sources of funding}

This study was supported by the Funding Program for Next Generation World-Leading Researchers (NEXT Program) from the Cabinet Office, Government of Japan, by PRESTO of the Japan Science and Technology Agency (JST), A-STEP of the JST, a Grant-in-Aid for Scientific Research from the Ministry of Education, Culture, Sports, Science and Technology (MEXT), a Grant-in-Aid for Japan Society for the Promotion of Science (JSPS) Fellows, a Research Grant for Cardiovascular Disease from the National Cardiovascular Center, Research Grants from the Mitsui Life Social Welfare Foundation, Takeda Science Foundation, Kanzawa Medical Research Foundation, Public Trust Fund for the Promotion of

Surgery, Suzuken Memorial Foundation, Japan Heart Foundation, The Naito Foundation, SENSHIN Medical Research Foundation, and The NOVARTIS Foundation (Japan) for the Promotion of Science.

\section{Disclosure statement}

None. 


\section{Figure Legends}

Figure 1. Changes in gene expression, neointimal hyperplasia, re-endothelialization and VSMC proliferation in the wire-induced vascular injury model. Femoral arteries were excised 28 days after injury. A, Real-time PCR analysis of total RNA extracted from the femoral arteries of WT and CGRP-/- mice. Relative gene expression of CLR and RAMP1 in WT and CGRP-/- mice, with (Injury) and without (Sham) wire-induced vascular injury, is shown. Median of the sham WT group was assigned a value of 1. Bars indicate means \pm $\mathrm{SE}\left(\mathrm{n}=5\right.$ for each); ${ }^{*} \mathrm{p}<0.05$ vs. sham-operated CGRP-/- mice. $\quad \mathbf{B}$, Representative sections stained with EVG to evaluate neointima formation. The arrows indicate the internal elastic lamina. $\quad$ Bar $=100 \mu \mathrm{m} . \quad \mathbf{C}-\mathbf{E}$, Bar graphs showing the neointimal area $(\mathbf{C})$, medial area (D) and Intima/Media ratio (E). Bars depict means $\pm \mathrm{SE}$ ( $\mathrm{n}=8$ for WT and 10 for CGRP-/-); ${ }^{*} \mathrm{p}<0.05, * * \mathrm{p}<0.01$ vs. WT. F, G, Evaluation of re-endothelialization. F, Representative photomicrographs of immunofluorescent staining for endothelial cells using anti-CD31 antibody. $\quad$ Bar $=200 \mu \mathrm{m} . \quad$ G, The bar graph shows the percent re-endothelialization of the injured areas. Bars depict means $\pm \mathrm{SE}(\mathrm{n}=3$ for each). H, I, Evaluation of VSMC proliferation. H, Representative photomicrographs showing immunohistochemical staining for VSMCs ( $\alpha$-SMA). Bar $=50 \mu \mathrm{m} . \quad$ I, Bar graph showing the comparison of $\alpha$-SMA-positive area. Bars depict means \pm SE ( $n=3$ for each) $* p<0.05$ vs. WT. 
Figure 2. Changes in inflammatory cytokine expression and inflammatory cell numbers in CGRP-/- mice. A, Quantitative real-time PCR analysis of the indicated inflammatory cytokines and macrophage markers in sham, and day 14 and 28 specimens after wire injury. Expression levels in CGRP-/- were normalized to WT, which was assigned a value of 1. Bars depict means $\pm \mathrm{SE}$ ( $\mathrm{n}=5$ for each from 2 independent experiments); ${ }^{*} \mathrm{P}<0.05 \mathrm{vs}$. WT. $\mathrm{ND}=$ not detected. $\quad \mathbf{B}$, Representative arterial sections showing immunohistochemical staining for macrophages $(\mathrm{F} 4 / 80)$ in sham and day 28 specimens after wire injury. $\quad$ Bar $=$ $200 \mu \mathrm{m}$. C, D, The bar graphs show F4/80-positive macrophage numbers in the neointimal (C) and adventitial (D) areas within each section. Bars depict means $\pm \mathrm{SE}(\mathrm{n}=3$ for each); ${ }^{*} \mathrm{p}<0.05$ vs. WT. E, Quantitative real-time PCR analysis of the indicated receptor elements of CGRP and cytokines in peritoneal macrophages. Median of the WT group was assigned a value of 1 . Bars depict means $\pm \mathrm{SE}$ ( $\mathrm{n}=5$ for each).

Figure 3. Increased oxidative stress within neointimal lesions in CGRP-/- arteries. A, Quantitative real-time PCR analysis of the indicated oxidative stress-related genes in sham and day 28 specimens after wire injury. Median of the WT group was assigned a value of 1 . Bars depict means $\pm \mathrm{SE}\left(\mathrm{n}=5\right.$ for each); $* * \mathrm{P}<0.01,{ }^{*} \mathrm{P}<0.05$ vs. WT. B, Representative photomicrographs (out of 3 independent femoral arteries in each group) showing 
immunohistochemical staining for $4 \mathrm{HNE}$ and p67phox. Bar $=200 \mu \mathrm{m}$. When immunostained for 4HNE (product of lipid peroxidation), CGRP-/- arteries showed intense staining after injury, especially in the adventitia.

Figure 4. Increased cellular proliferation within neointimal lesions in CGRP-/- arteries. A, Representative photomicrographs of arteries immunostained for PCNA. DAPI staining was used to visualize the nuclei. Mouse IgG2a was used as a negative control of the immunostaining. $\quad$ Bar $=50 \mu \mathrm{m} . \quad \mathbf{B}$, Percentage of PCNA-positive cells within the neointimal lesions. Bars depict means $\pm \mathrm{SE}$ ( $\mathrm{n}=3$ for each); ${ }^{*} \mathrm{p}<0.05$ vs. WT.

Figure 5. Bone marrow cells contribute little to neointima formation in CGRP-/- arteries. The sample sections were stained with EVG and neointimal formation was evaluated. A, Representative photomicrographs of EVG stained arteries following wire injury in bone marrow-transplanted mice $\left[\mathrm{BMT}^{\mathrm{WT} \rightarrow \mathrm{WT}}(\mathrm{n}=6), \mathrm{BMT}^{\mathrm{CGRP}-/ \rightarrow \mathrm{WT}}(\mathrm{n}=5)\right] . \quad$ The arrows indicate the internal elastic lamina. $\quad B a r=100 \mu \mathrm{m} . \quad$ B-D, The bar graphs show the neointimal area (B), medial area (C) and intima/media ratio (D). Bars depict means $\pm \mathrm{SE}$.

Figure 6. CGRP suppresses VSMC proliferation, migration, and ERK activation in vitro. With CGRP $\left(10^{-10}-10^{-6} \mathrm{M}\right)$ under PDGF-BB (10 ng/ml)-stimulation, rat or mouse VSMC 
proliferation and migration were analyzed using BrdU assays $(\mathbf{A}, \mathbf{B}, \mathbf{D}, \mathbf{E})$ and scratch assays (C). A, The effect of various doses of CGRP on rat VSMCs. B, Time course of the effect of CGRP $\left(10^{-7} \mathrm{M}\right)$ on proliferation of rat VSMCs. C, Representative micrographic photos at $0 \mathrm{~h}$ and $12 \mathrm{~h}$ of the scratch assay using rat VSMCs and bar graphs showing the migration area for $12 \mathrm{~h}$ are shown. D, The effect of CGRP $\left(10^{-7} \mathrm{M}\right)$ on mouse VSMC proliferation. E, Comparison of VSMC proliferation cultured from WT and CGRP-/- mice. For the study of A-E, experiments were repeated independently 3 times. In each experiment, $n=8$ in $\mathbf{A}, \mathbf{B}, \mathbf{D}$, and $\mathbf{E}$ and $n=5$ in $\mathbf{C}$. Representative results are shown in the graphs. Bars depict means \pm $\mathrm{SE} ; * * * \mathrm{P}<0.001, * * \mathrm{P}<0.01, * \mathrm{P}<0.05$ vs. Control (Ctrl).

F, Western blotting of ERK1/2 and p-ERK1/2 under stimulation with or without 1 h CGRP $\left(10^{-9}-10^{-7} \mathrm{M}\right)$-treatment. Optical densities were quantified and the result of the ratio of relative phosphorylation of ERK1/2 is shown in the bar graph. p-ERK1/2 / ERK1/2 is set to 1 for the control group. Bars depict means $\pm \mathrm{SE}(\mathrm{n}=3$ for each); $* \mathrm{P}<0.05$ vs. Control (Ctrl).

Table 1. Primers and probes used for quantitative real-time RT-PCR 


\section{References}

[1] Costa MA, Simon DI. Molecular basis of restenosis and drug-eluting stents. Circulation. 2005;111:2257-73.

[2] Welt FG, Rogers C. Inflammation and restenosis in the stent era. Arterioscler Thromb Vasc Biol. 2002;22:1769-76.

[3] Ross R. Atherosclerosis--an inflammatory disease. N Engl J Med. 1999;340:115-26.

[4] Marx SO, Totary-Jain H, Marks AR. Vascular smooth muscle cell proliferation in restenosis. Circ Cardiovasc Interv.4:104-11.

[5] Dzau VJ, Braun-Dullaeus RC, Sedding DG. Vascular proliferation and atherosclerosis: new perspectives and therapeutic strategies. Nat Med. 2002;8:1249-56.

[6] Wu L, Iwai M, Nakagami H, Li Z, Chen R, Suzuki J, et al. Roles of angiotensin II type 2 receptor stimulation associated with selective angiotensin II type 1 receptor blockade with valsartan in the improvement of inflammation-induced vascular injury. Circulation. 2001;104:2716-21.

[7] Duckers HJ, Boehm M, True AL, Yet SF, San H, Park JL, et al. Heme oxygenase-1 protects against vascular constriction and proliferation. Nat Med. 2001;7:693-8.

[8] Shi Y, Niculescu R, Wang D, Patel S, Davenpeck KL, Zalewski A. Increased NAD(P)H oxidase and reactive oxygen species in coronary arteries after balloon injury. Arterioscler 
Thromb Vasc Biol. 2001;21:739-45.

[9] Patterson C, Ruef J, Madamanchi NR, Barry-Lane P, Hu Z, Horaist C, et al. Stimulation of a vascular smooth muscle cell NAD(P)H oxidase by thrombin. Evidence that p47(phox) may participate in forming this oxidase in vitro and in vivo. $\mathrm{J}$ Biol Chem. $1999 ; 274: 19814-22$.

[10] Rosenfeld MG, Mermod JJ, Amara SG, Swanson LW, Sawchenko PE, Rivier J, et al. Production of a novel neuropeptide encoded by the calcitonin gene via tissue-specific RNA processing. Nature. 1983;304:129-35.

[11] Holzer P. Local effector functions of capsaicin-sensitive sensory nerve endings: involvement of tachykinins, calcitonin gene-related peptide and other neuropeptides. Neuroscience. 1988;24:739-68.

[12] Wimalawansa SJ. Calcitonin gene-related peptide and its receptors: molecular genetics, physiology, pathophysiology, and therapeutic potentials. Endocrine reviews. 1996;17:533-85. [13] Deng PY, Li YJ. Calcitonin gene-related peptide and hypertension. Peptides. 2005;26:1676-85.

[14] Li XW, Hu CP, Wu WH, Zhang WF, Zou XZ, Li YJ. Inhibitory effect of calcitonin gene-related peptide on hypoxia-induced rat pulmonary artery smooth muscle cells proliferation: role of ERK1/2 and p27. European journal of pharmacology. 2012;679:117-26.

[15] Chattergoon NN, D'Souza FM, Deng W, Chen H, Hyman AL, Kadowitz PJ, et al. 
Antiproliferative effects of calcitonin gene-related peptide in aortic and pulmonary artery smooth muscle cells. Am J Physiol Lung Cell Mol Physiol. 2005;288:L202-11.

[16] Thievent A, Sena S, Parlakian A, Breuzard G, Beley A, Rochette L, et al. Potential role of the neuropeptide CGRP in the induction of differentiation of rat hepatic portal vein wall. Peptides. 2005;26:1567-72.

[17] Supowit SC, Rao A, Bowers MC, Zhao H, Fink G, Steficek B, et al. Calcitonin gene-related peptide protects against hypertension-induced heart and kidney damage. Hypertension. 2005;45:109-14.

[18] Yoneda M, Sato Y, Nakamura K, Yokohama S, Kono T, Watanobe H, et al. Involvement of calcitonin gene-related peptide and capsaicin-sensitive afferents in central thyrotropin-releasing hormone-induced hepatic cytoprotection. Eur $\mathrm{J}$ Pharmacol. $2003 ; 478: 173-7$.

[19] Bennett GS, Garrett NE, Diemel LT, Brain SD, Tomlinson DR. Neurogenic cutaneous vasodilatation and plasma extravasation in diabetic rats: effect of insulin and nerve growth factor. Br J Pharmacol. 1998;124:1573-9.

[20] Bunker CB, Reavley C, O'Shaughnessy DJ, Dowd PM. Calcitonin gene-related peptide in treatment of severe peripheral vascular insufficiency in Raynaud's phenomenon. Lancet. $1993 ; 342: 80-3$.

[21] Kawai J, Ando K, Tojo A, Shimosawa T, Takahashi K, Onozato ML, et al. Endogenous 
adrenomedullin protects against vascular response to injury in mice. Circulation. 2004;109:1147-53.

[22] Kohno M, Yasunari K, Minami M, Kano H, Maeda K, Mandal AK, et al. Regulation of rat mesangial cell migration by platelet-derived growth factor, angiotensin II, and adrenomedullin. Journal of the American Society of Nephrology : JASN. 1999;10:2495-502.

[23] Qin XP, Ye F, Hu CP, Liao DF, Deng HW, Li YJ. Effect of calcitonin gene-related peptide on angiotensin II-induced proliferation of rat vascular smooth muscle cells. Eur J Pharmacol. 2004;488:45-9.

[24] Sata M, Saiura A, Kunisato A, Tojo A, Okada S, Tokuhisa T, et al. Hematopoietic stem cells differentiate into vascular cells that participate in the pathogenesis of atherosclerosis. Nature medicine. 2002;8:403-9.

[25] Oh-hashi Y, Shindo T, Kurihara Y, Imai T, Wang Y, Morita H, et al. Elevated sympathetic nervous activity in mice deficient in alphaCGRP. Circ Res. 2001;89:983-90.

[26] Sata M, Maejima Y, Adachi F, Fukino K, Saiura A, Sugiura S, et al. A mouse model of vascular injury that induces rapid onset of medial cell apoptosis followed by reproducible neointimal hyperplasia. J Mol Cell Cardiol. 2000;32:2097-104.

[27] Yoshioka T, Takahashi M, Shiba Y, Suzuki C, Morimoto H, Izawa A, et al. Granulocyte colony-stimulating factor (G-CSF) accelerates reendothelialization and reduces neointimal formation after vascular injury in mice. Cardiovasc Res. 2006;70:61-9. 
[28] Kobayashi M, Inoue K, Warabi E, Minami T, Kodama T. A simple method of isolating mouse aortic endothelial cells. J Atheroscler Thromb. 2005;12:138-42.

[29] Ray JL, Leach R, Herbert JM, Benson M. Isolation of vascular smooth muscle cells from a single murine aorta. Methods in cell science : an official journal of the Society for In Vitro Biology. 2001;23:185-8.

[30] Hirata Y, Takagi Y, Takata S, Fukuda Y, Yoshimi H, Fujita T. Calcitonin gene-related peptide receptor in cultured vascular smooth muscle and endothelial cells. Biochemical and biophysical research communications. 1988;151:1113-21.

[31] Tanaka K, Sata M, Hirata Y, Nagai R. Diverse contribution of bone marrow cells to neointimal hyperplasia after mechanical vascular injuries. Circ Res. 2003;93:783-90.

[32] Sueur S, Pesant M, Rochette L, Connat JL. Antiapoptotic effect of calcitonin gene-related peptide on oxidative stress-induced injury in $\mathrm{H} 9 \mathrm{c} 2$ cardiomyocytes via the RAMP1/CRLR complex. J Mol Cell Cardiol. 2005;39:955-63.

[33] Kamiyoshi A, Sakurai T, Ichikawa-Shindo Y, Fukuchi J, Kawate H, Muto S, et al. Endogenous alphaCGRP protects against concanavalin A-induced hepatitis in mice. Biochem Biophys Res Commun. 2006;343:152-8.

[34] Li W, Wang T, Ma C, Xiong T, Zhu Y, Wang X. Calcitonin gene-related peptide inhibits interleukin-1beta-induced endogenous monocyte chemoattractant protein-1 secretion in type II alveolar epithelial cells. Am J Physiol Cell Physiol. 2006;291:C456-65. 
[35] Schneider L, Hartwig W, Flemming T, Hackert T, Fortunato F, Heck M, et al. Protective effects and anti-inflammatory pathways of exogenous calcitonin gene-related peptide in severe necrotizing pancreatitis. Pancreatology. 2009;9:662-9.

[36] Zhang X, Zhuang J, Wu H, Chen Z, Su J, Chen S, et al. Inhibitory effects of calcitonin gene-related peptides on experimental vein graft disease. The Annals of thoracic surgery. 2010;90:117-23.

[37] Yajima N, Takahashi M, Morimoto H, Shiba Y, Takahashi Y, Masumoto J, et al. Critical role of bone marrow apoptosis-associated speck-like protein, an inflammasome adaptor molecule, in neointimal formation after vascular injury in mice. Circulation. 2008;117:3079-87.

[38] Koundrioukoff S, Jonsson ZO, Hasan S, de Jong RN, van der Vliet PC, Hottiger MO, et al. A direct interaction between proliferating cell nuclear antigen (PCNA) and Cdk2 targets PCNA-interacting proteins for phosphorylation. J Biol Chem. 2000;275:22882-7.

[39] Das M, Bouchey DM, Moore MJ, Hopkins DC, Nemenoff RA, Stenmark KR. Hypoxia-induced proliferative response of vascular adventitial fibroblasts is dependent on $\mathrm{g}$ protein-mediated activation of mitogen-activated protein kinases. $\mathrm{J}$ Biol Chem. 2001;276:15631-40.

[40] Touyz RM, Deng LY, He G, Wu XH, Schiffrin EL. Angiotensin II stimulates DNA and protein synthesis in vascular smooth muscle cells from human arteries: role of extracellular 
signal-regulated kinases. J Hypertens. 1999;17:907-16.

[41] Schramm A, Matusik P, Osmenda G, Guzik TJ. Targeting NADPH oxidases in vascular pharmacology. Vascular pharmacology. 2012;56:216-31.

[42] Brain SD, Grant AD. Vascular actions of calcitonin gene-related peptide and adrenomedullin. Physiol Rev. 2004;84:903-34.

[43] Zheng S, Li W, Xu M, Bai X, Zhou Z, Han J, et al. Calcitonin gene-related peptide promotes angiogenesis via AMP-activated protein kinase. Am J Physiol Cell Physiol. 2010;299:C1485-92.

[44] Gray DW, Marshall I. Nitric oxide synthesis inhibitors attenuate calcitonin gene-related peptide endothelium-dependent vasorelaxation in rat aorta. Eur J Pharmacol. 1992;212:37-42. [45] Wisskirchen FM, Burt RP, Marshall I. Pharmacological characterization of CGRP receptors mediating relaxation of the rat pulmonary artery and inhibition of twitch responses of the rat vas deferens. Br J Pharmacol. 1998;123:1673-83.

[46] Saito A, Masaki T, Uchiyama Y, Lee TJ, Goto K. Calcitonin gene-related peptide and vasodilator nerves in large cerebral arteries of cats. The Journal of pharmacology and experimental therapeutics. 1989;248:455-62.

[47] Wellman GC, Quayle JM, Standen NB. ATP-sensitive K+ channel activation by calcitonin gene-related peptide and protein kinase A in pig coronary arterial smooth muscle. The Journal of physiology. 1998;507 ( Pt 1):117-29. 
[48] Bol M, Leybaert L, Vanheel B. Influence of methanandamide and CGRP on potassium currents in smooth muscle cells of small mesenteric arteries. Pflugers Archiv : European journal of physiology. 2012;463:669-77.

[49] Zhou Z, Hu CP, Wang CJ, Li TT, Peng J, Li YJ. Calcitonin gene-related peptide inhibits angiotensin II-induced endothelial progenitor cells senescence through up-regulation of klotho expression. Atherosclerosis. 2010;213:92-101.

[50] Kong D, Melo LG, Gnecchi M, Zhang L, Mostoslavsky G, Liew CC, et al. Cytokine-induced mobilization of circulating endothelial progenitor cells enhances repair of injured arteries. Circulation. 2004;110:2039-46.

[51] Gulati R, Jevremovic D, Peterson TE, Witt TA, Kleppe LS, Mueske CS, et al. Autologous culture-modified mononuclear cells confer vascular protection after arterial injury. Circulation. 2003;108:1520-6. 


\begin{tabular}{|c|c|c|}
\hline CRLR & $\begin{array}{l}\text { Forward } \\
\text { Reverse } \\
\text { Probe }\end{array}$ & $\begin{array}{l}\text { AGGCGTTTACCTGCACACACT } \\
\text { CAGGAAGCAGAGGAAACCCC } \\
\text { ATCGTGGTGGCTGTGTTTGCGGAG }\end{array}$ \\
\hline RAMP1 & $\begin{array}{l}\text { Forward } \\
\text { Reverse } \\
\text { Probe }\end{array}$ & $\begin{array}{l}\text { GCACTGGTGGTCTGGAGGA } \\
\text { CCCTCATCACCTGGGATACCT } \\
\text { GCGCACAGAGGGCATCGTG }\end{array}$ \\
\hline CGRP & $\begin{array}{l}\text { Forward } \\
\text { Reverse }\end{array}$ & $\begin{array}{l}\text { GGAGCAGGAGGAAGAGCAG } \\
\text { TGCCAGCCGATGGGTCACA }\end{array}$ \\
\hline TNF- $\alpha$ & $\begin{array}{l}\text { Forward } \\
\text { Reverse }\end{array}$ & $\begin{array}{l}\text { ACGGCATGGATCTCAAAGAC } \\
\text { AGATAGCAAATCGGCTGACG }\end{array}$ \\
\hline MCP-1 & $\begin{array}{l}\text { Forward } \\
\text { Reverse }\end{array}$ & $\begin{array}{l}\text { GCAGTTAACGCCCCACTCA } \\
\text { CCTACTCATTGGGATCATCTTGCT }\end{array}$ \\
\hline $\mathrm{F} 4 / 80$ & $\begin{array}{l}\text { Forward } \\
\text { Reverse }\end{array}$ & $\begin{array}{l}\text { GATGAATTCCCGTGTTGTTGGT } \\
\text { ACATCAGTGTTCCAGGAGACACA }\end{array}$ \\
\hline CCR2 & $\begin{array}{l}\text { Forward } \\
\text { Reverse }\end{array}$ & $\begin{array}{l}\text { GCTCAACTTGGCCATCTCTGA } \\
\text { AGACCCACTCATTTGCAGCAT }\end{array}$ \\
\hline CD68 & $\begin{array}{l}\text { Forward } \\
\text { Reverse }\end{array}$ & $\begin{array}{l}\text { TGGCGGTGGAATACAATGTG } \\
\text { GAGATGAATTCTGCGCCATGA }\end{array}$ \\
\hline TGF- $\beta$ & $\begin{array}{l}\text { Forward } \\
\text { Reverse }\end{array}$ & $\begin{array}{l}\text { CCCGAAGCGGACTACTATGC } \\
\text { TAGATGGCGTTGTTGCGGT }\end{array}$ \\
\hline IL-6 & $\begin{array}{l}\text { Forward } \\
\text { Reverse }\end{array}$ & $\begin{array}{l}\text { CCCAATTTCCAATGCTCTCC } \\
\text { TGAATTGGATGGTCTTGGTCC }\end{array}$ \\
\hline IL- $1 \beta$ & $\begin{array}{l}\text { Forward } \\
\text { Reverse }\end{array}$ & $\begin{array}{l}\text { TCTCACAGCAGCACATCAAC } \\
\text { TCGTTGCTTGGTTCTCCTTG }\end{array}$ \\
\hline eNOS & $\begin{array}{l}\text { Forward } \\
\text { Reverse }\end{array}$ & $\begin{array}{l}\text { AGGCACTGCTGAGCCGAGT } \\
\text { TTCTCCAGTTGTTCCACAGCC }\end{array}$ \\
\hline P22 phox & $\begin{array}{l}\text { Forward } \\
\text { Reverse }\end{array}$ & $\begin{array}{l}\text { GGCCATTGCCAGTGTGATCT } \\
\text { GCTCAATGGGAGTCCACTGC }\end{array}$ \\
\hline P47 phox & $\begin{array}{l}\text { Forward } \\
\text { Reverse }\end{array}$ & $\begin{array}{l}\text { ATCCTATCTGGAGCCCCTTGA } \\
\text { CACCTGCGTAGTTGGGATCC }\end{array}$ \\
\hline P67 phox & $\begin{array}{l}\text { Forward } \\
\text { Reverse }\end{array}$ & $\begin{array}{l}\text { CAGACCCAAAACCCCAGAAA } \\
\text { AAAGCCAAACAATACGCGGT }\end{array}$ \\
\hline
\end{tabular}

\section{Table. 1}


A

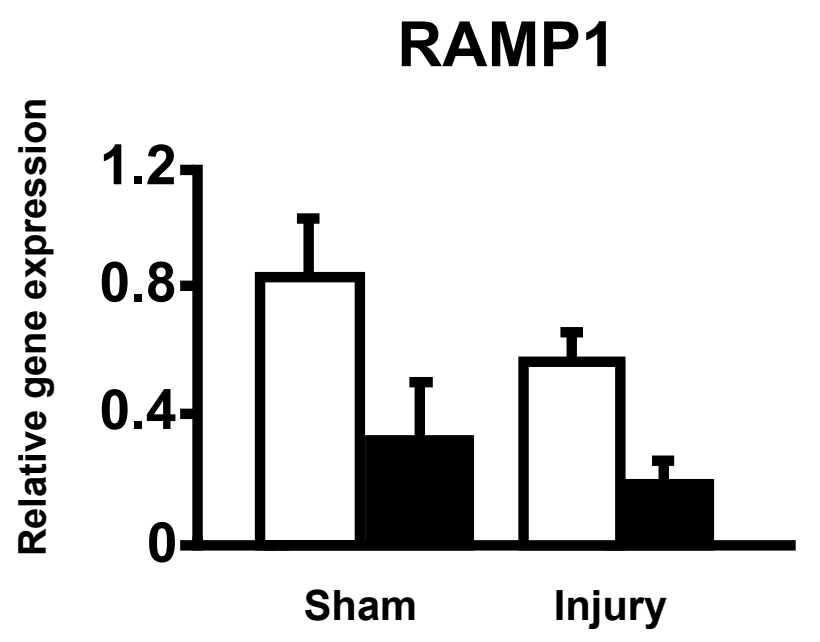

$\square$ wT

CGRP-/-
CLR

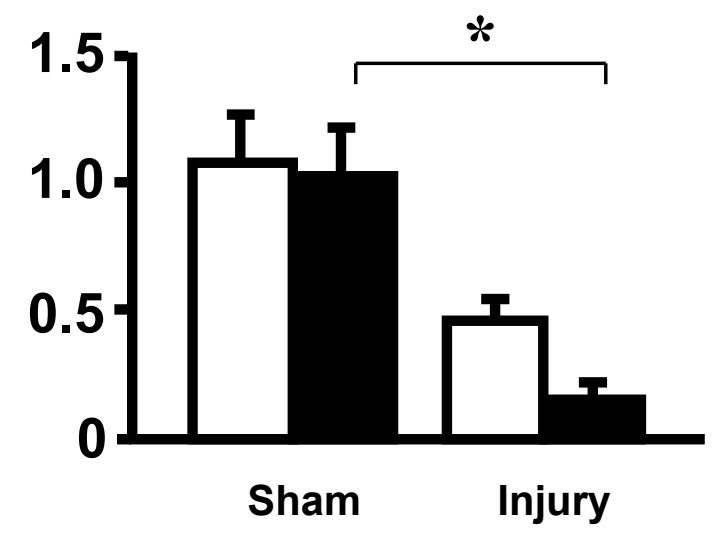

Fig. 1 
B

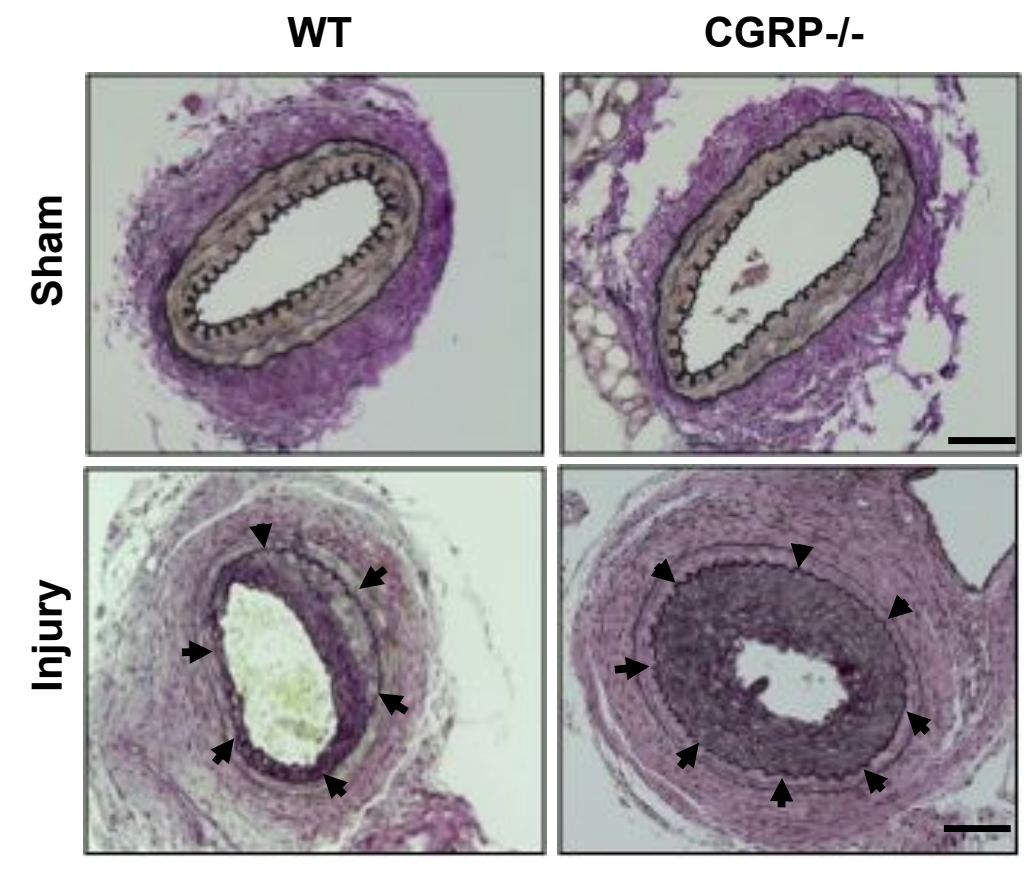

C

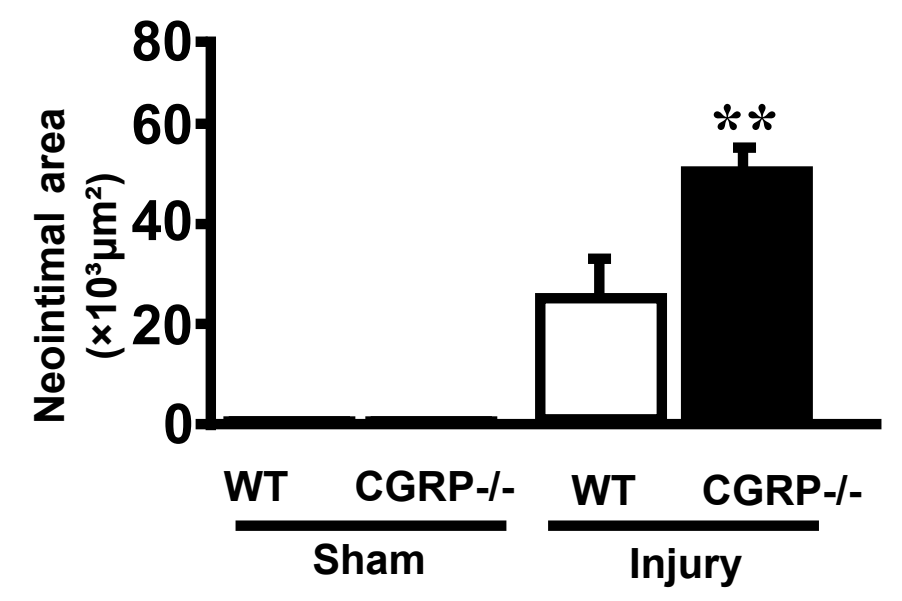

WT Injury

CGRP-/- Injury

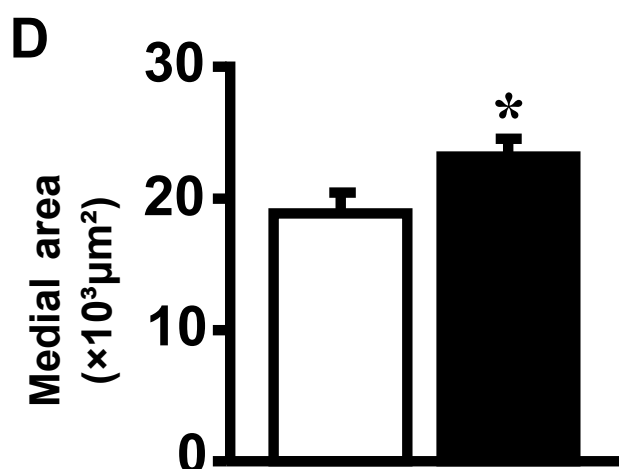

E

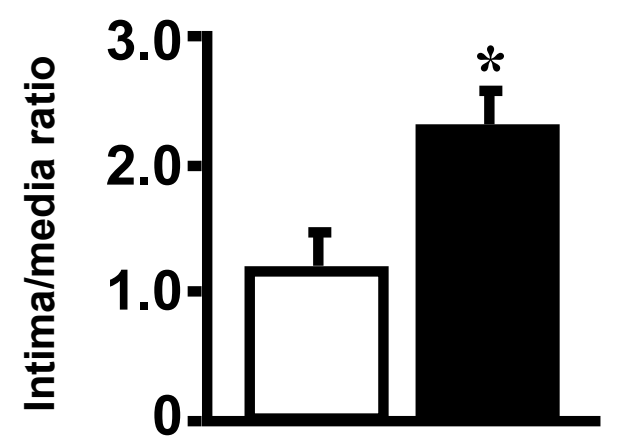

Fig. 1 


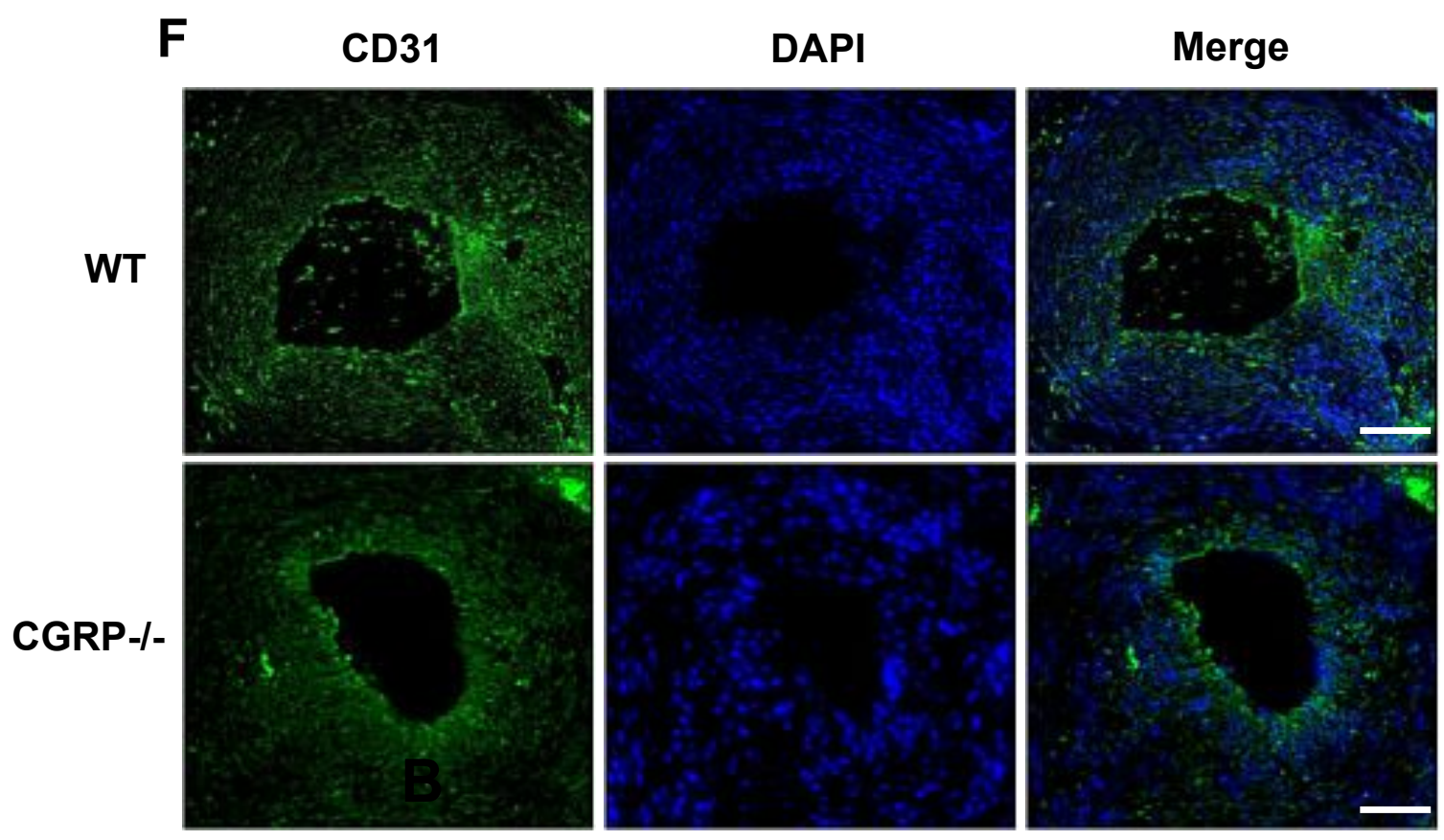

G

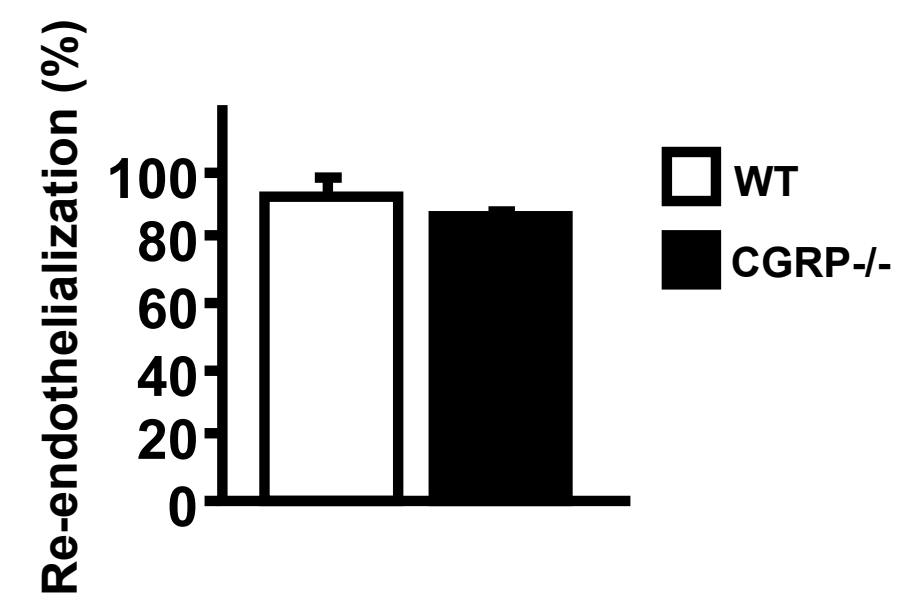

Fig. 1 

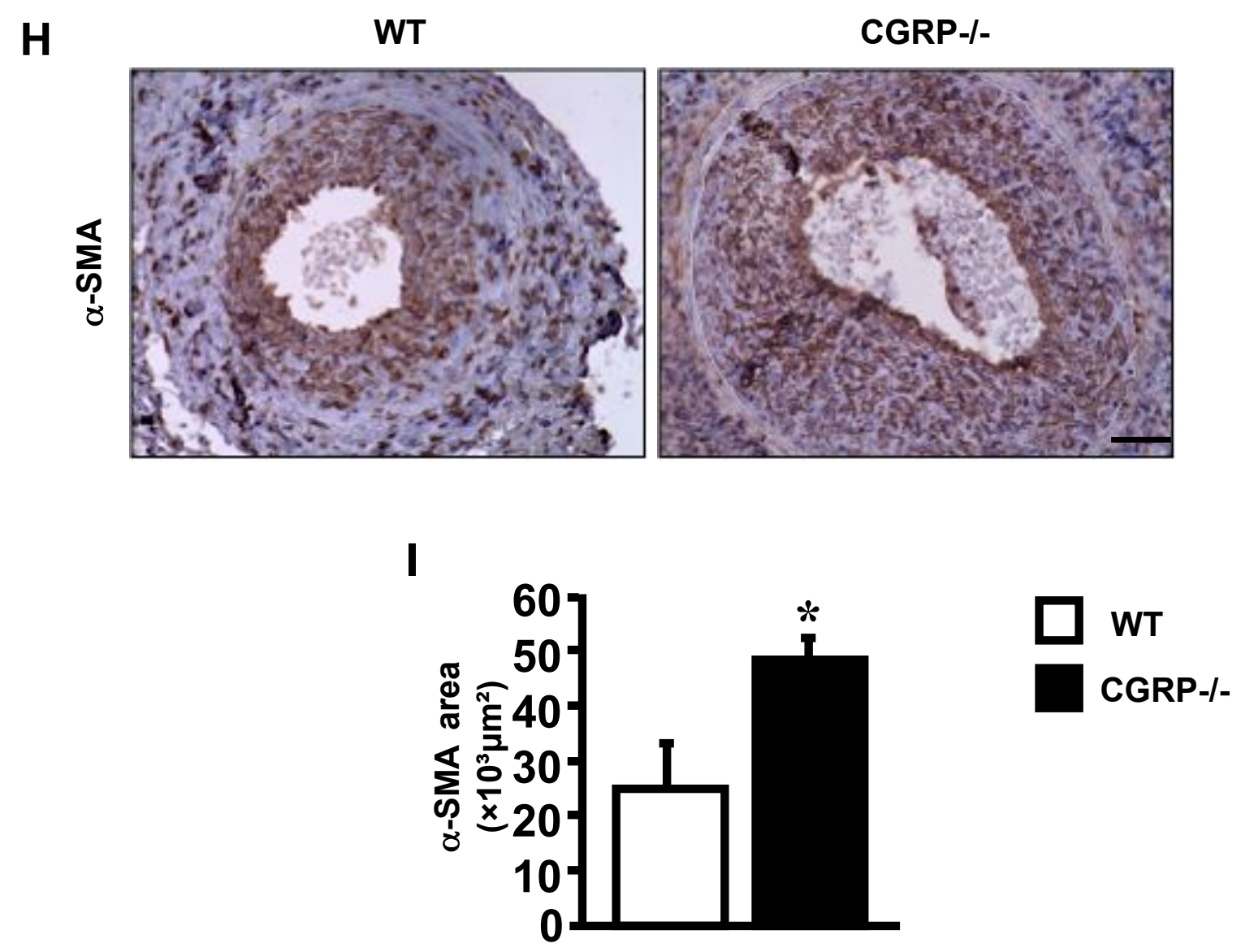

Fig. 1 
A

Sham

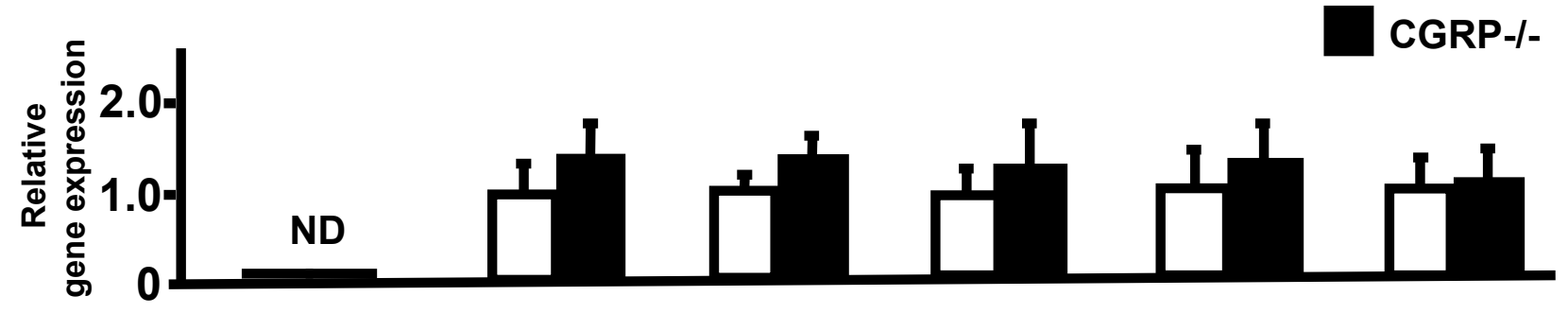

Day14 2.0 -
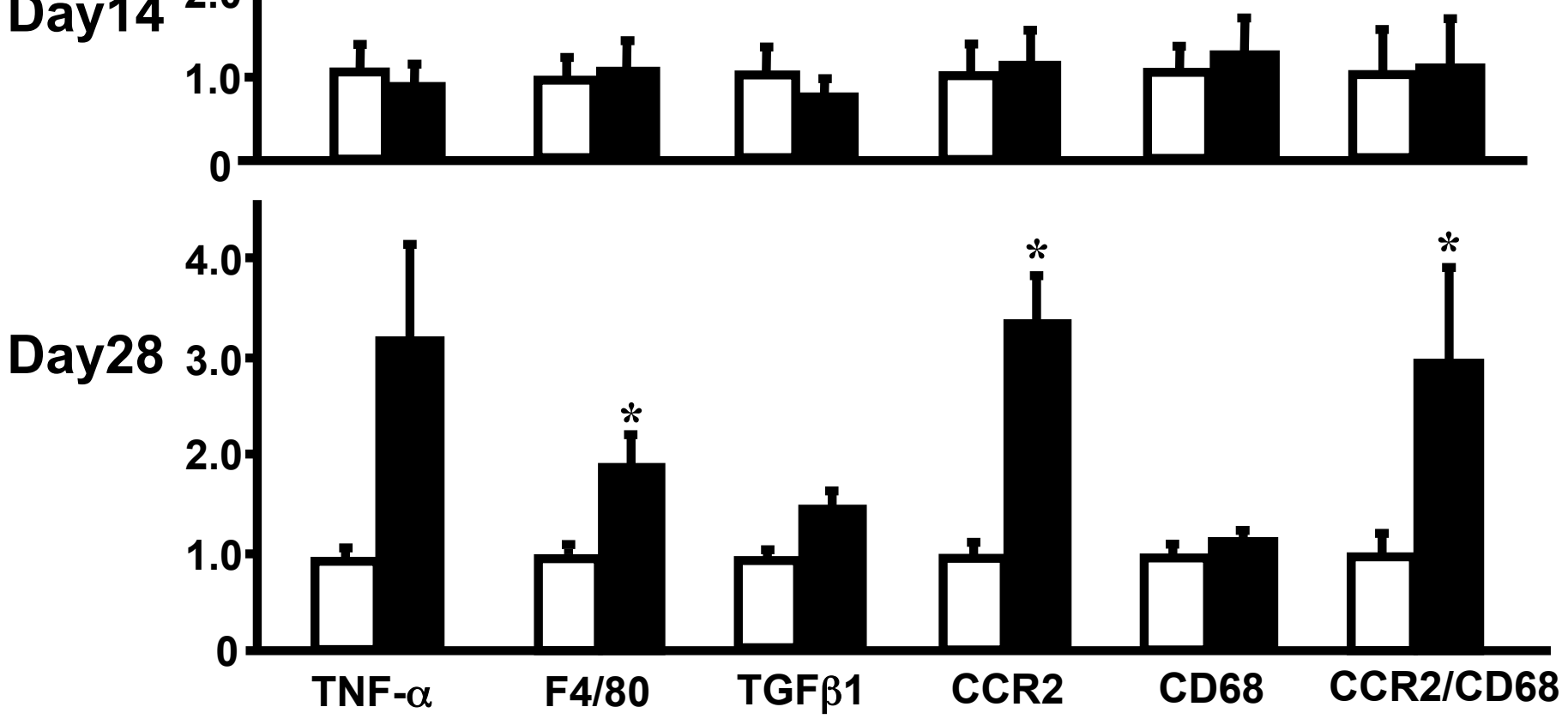

Fig. 2 


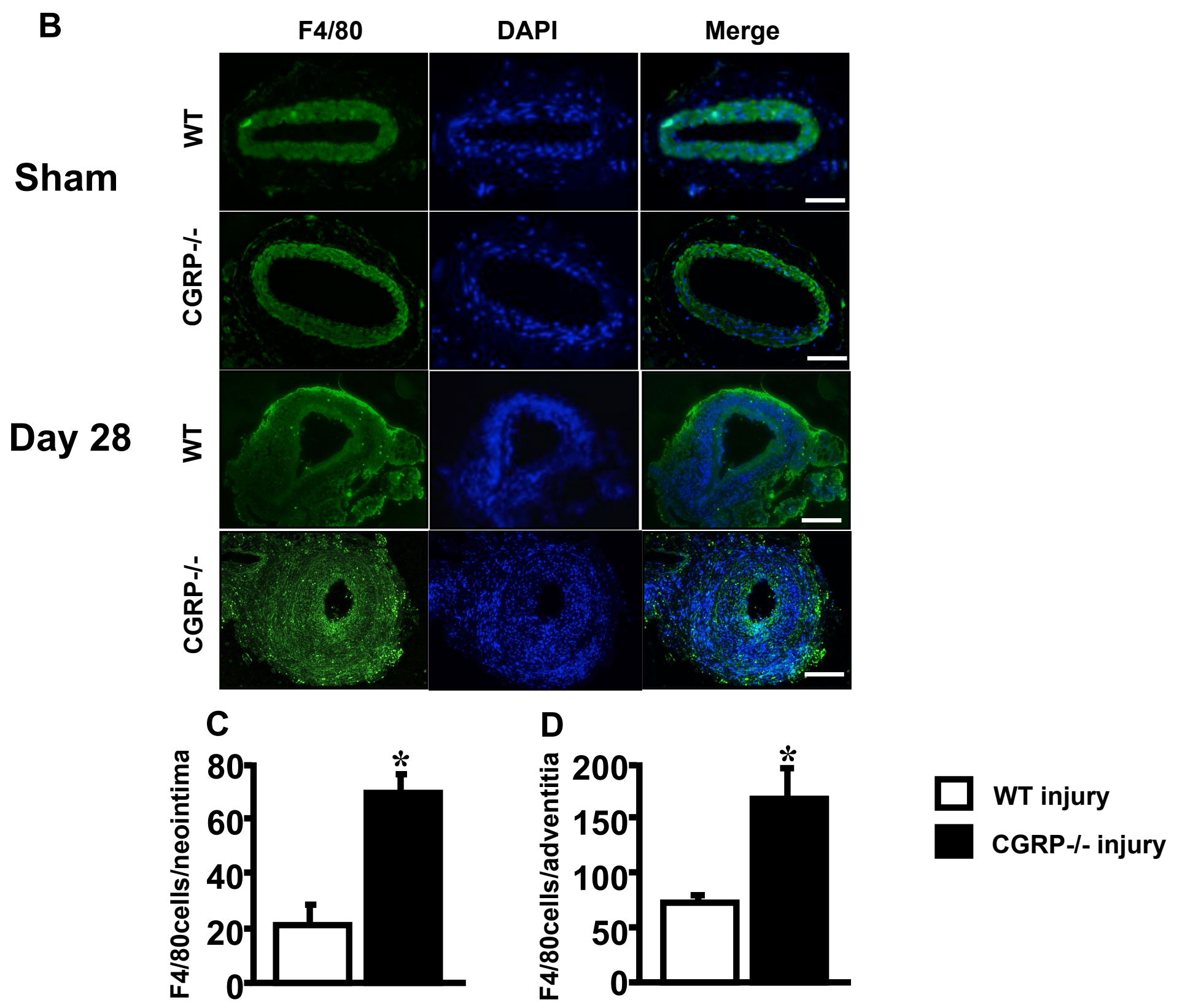

Fig. 2 
E

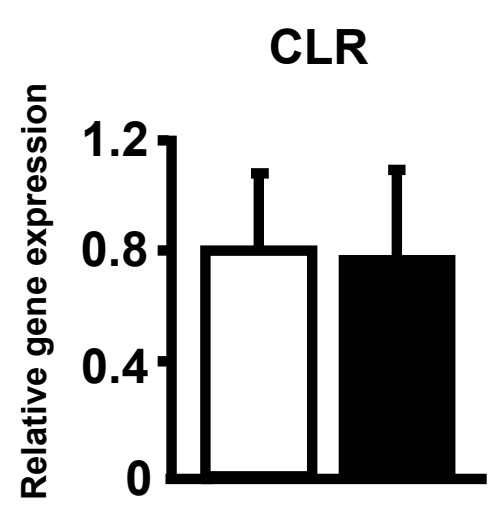

RAMP1

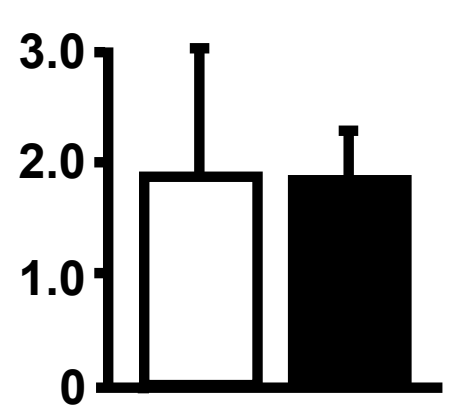

$\square$ WT

CGRP-/-

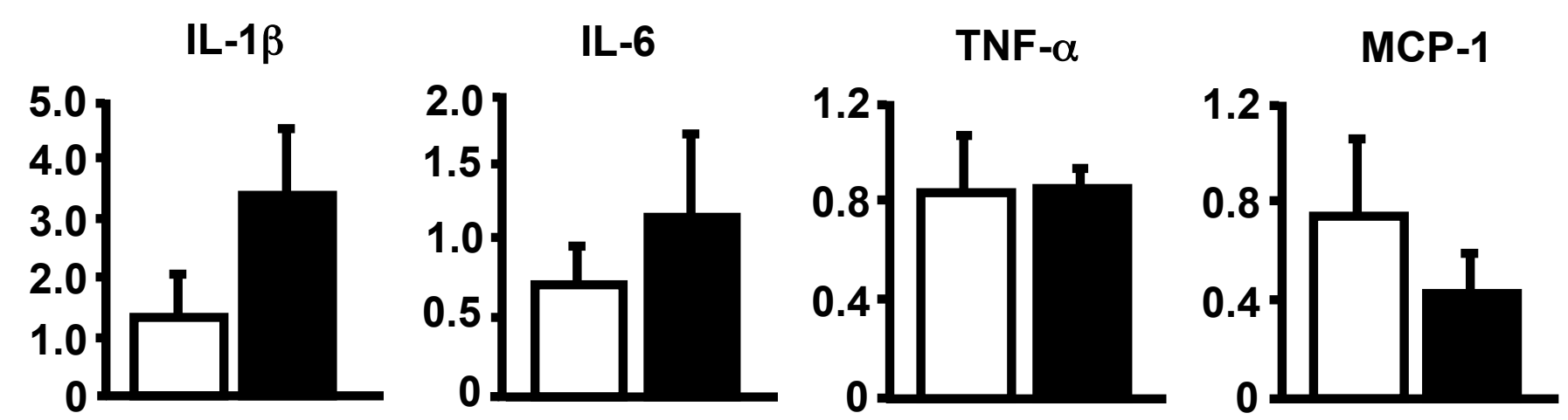

Fig. 2 
A
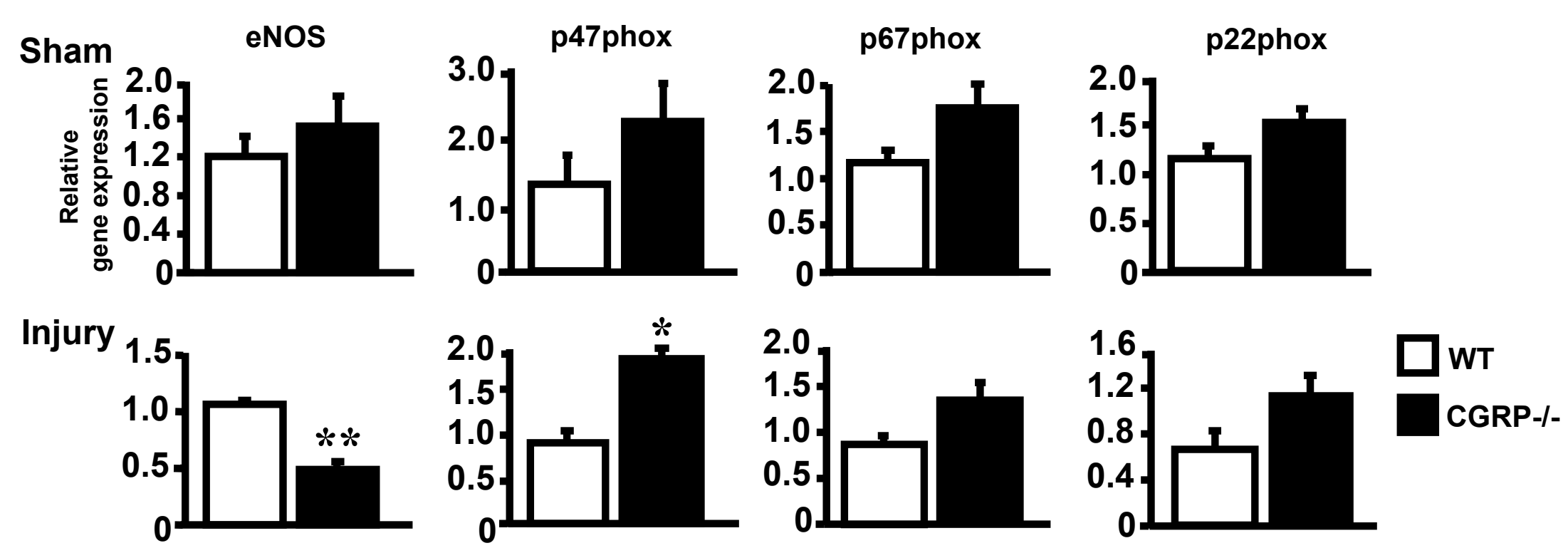

B

Sham
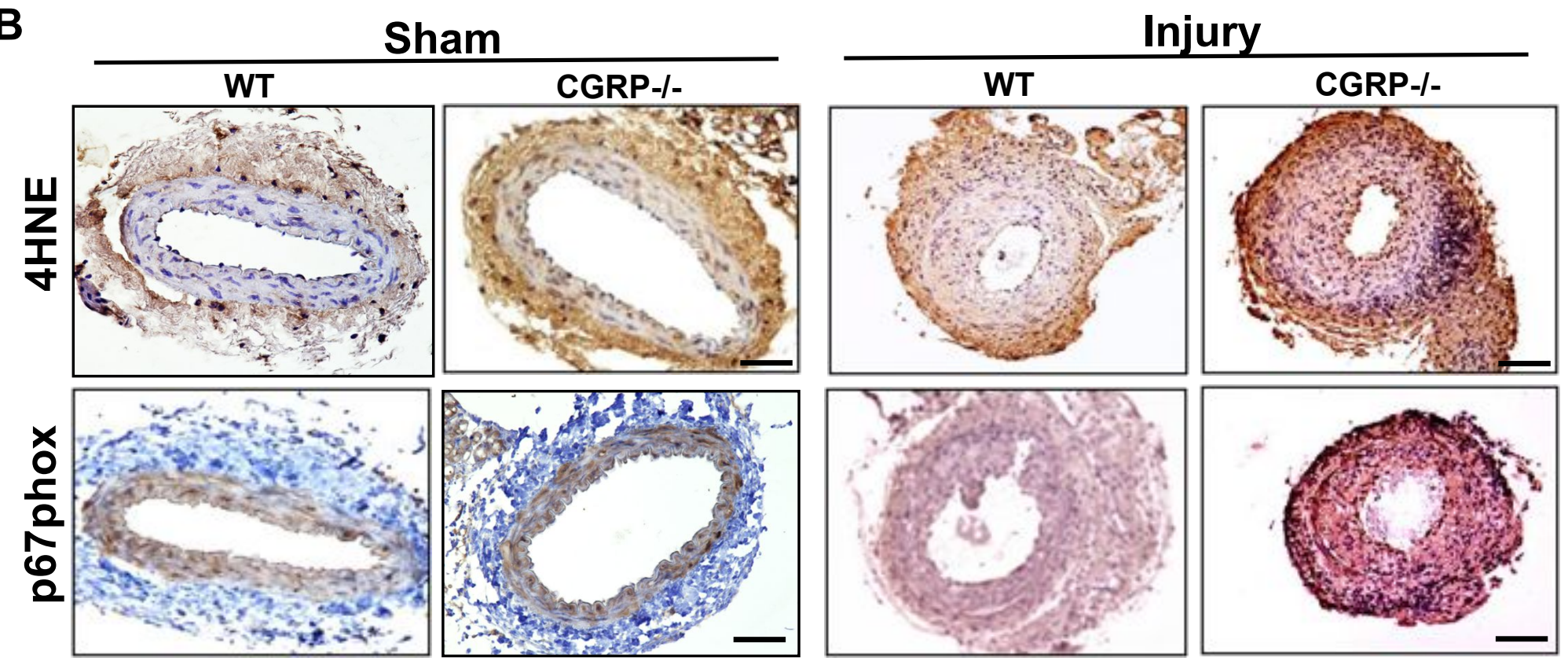

Fig. 3 


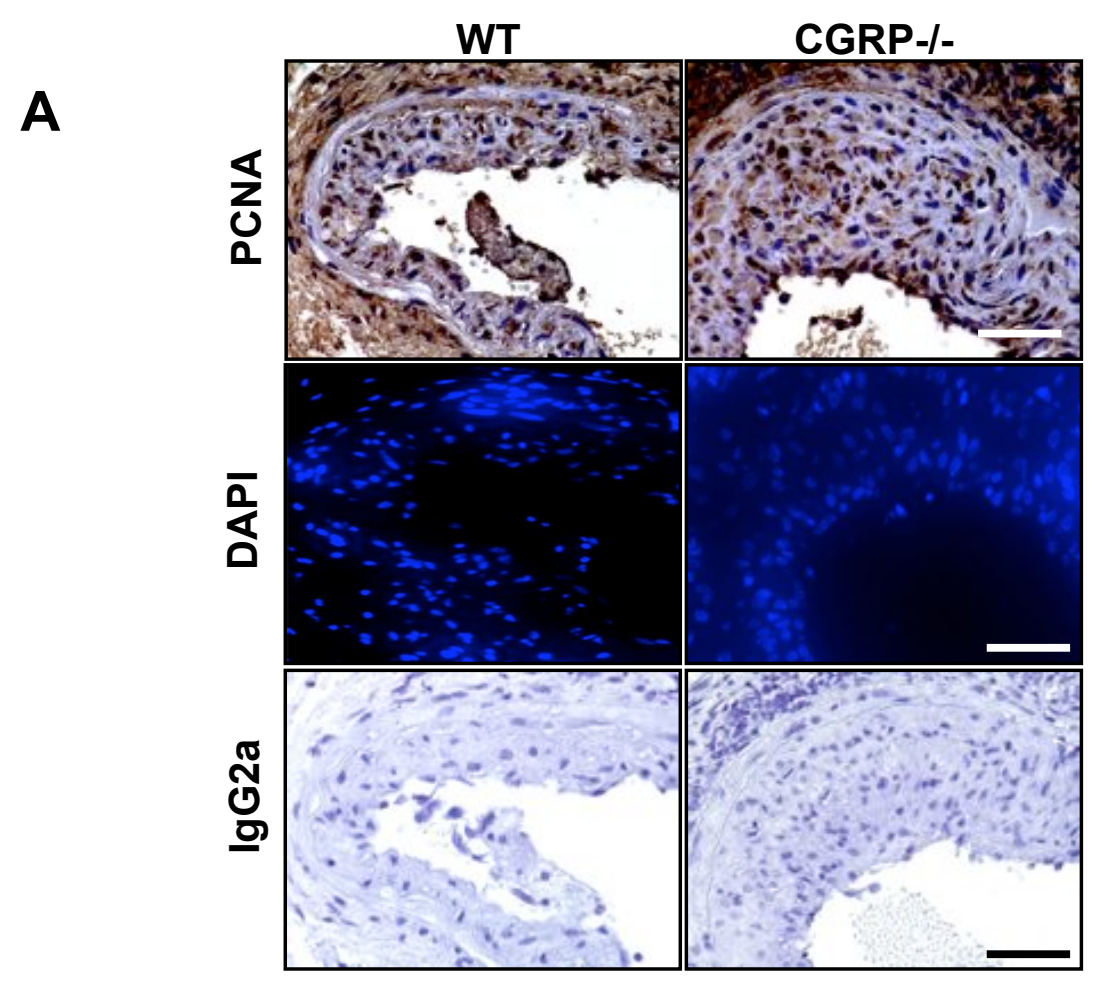

B

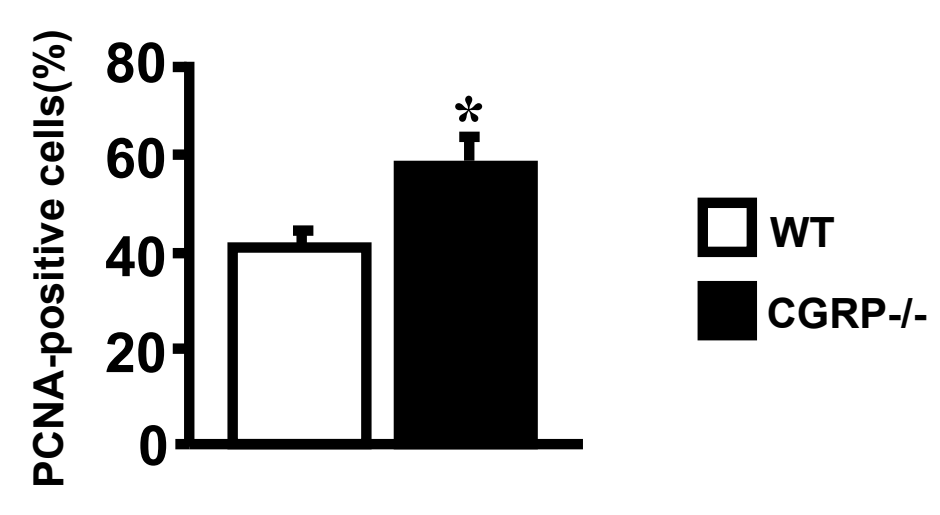

Fig. 4 

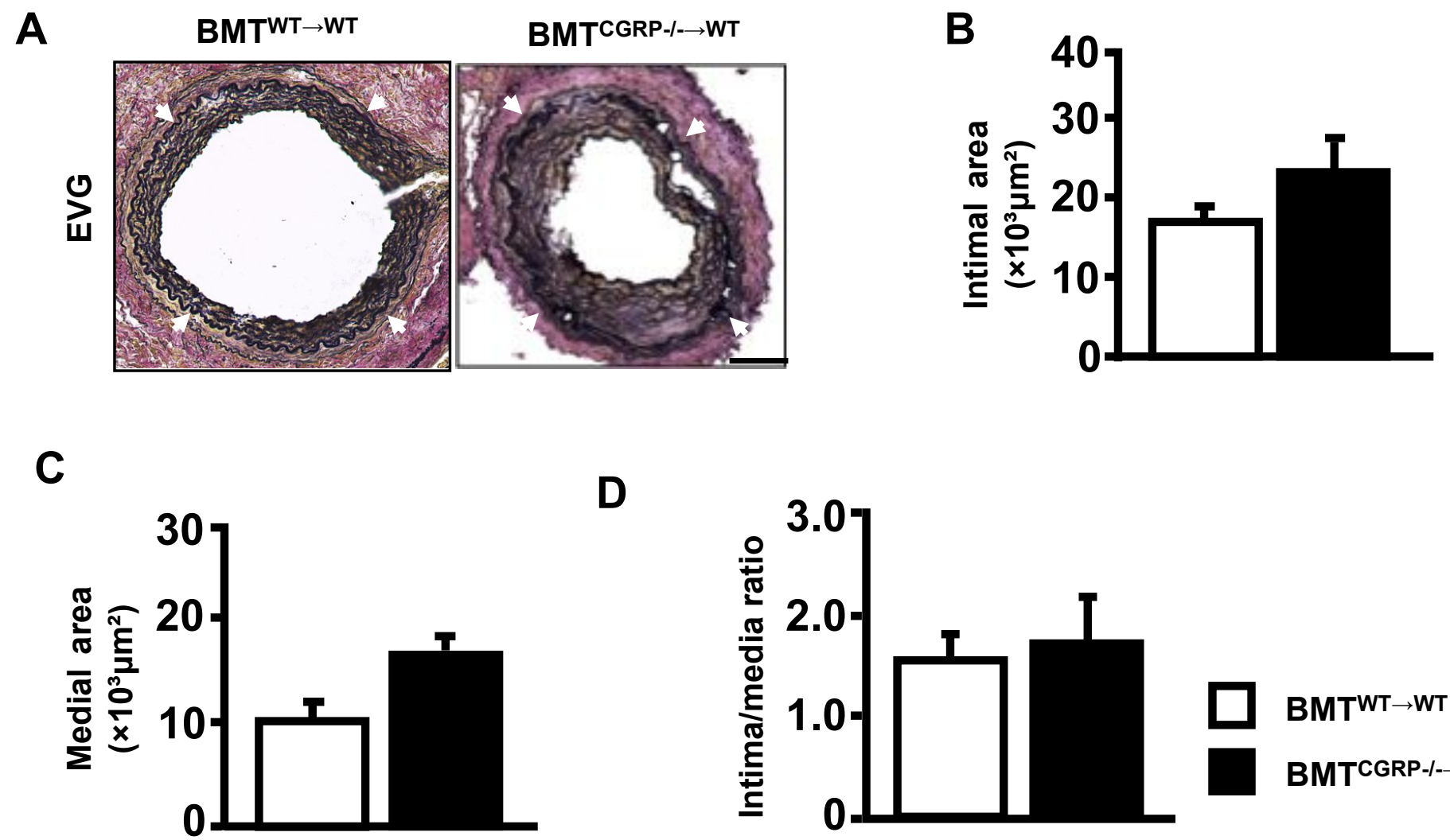

D

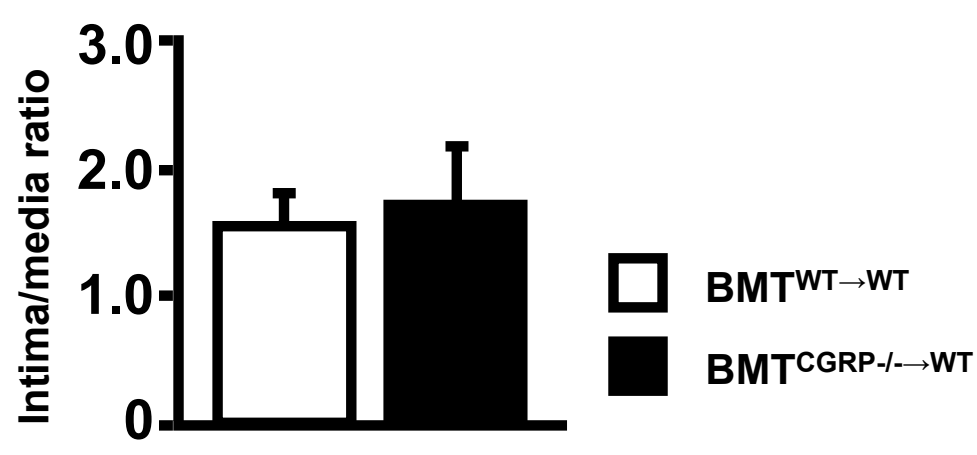

Fig. 5 
A

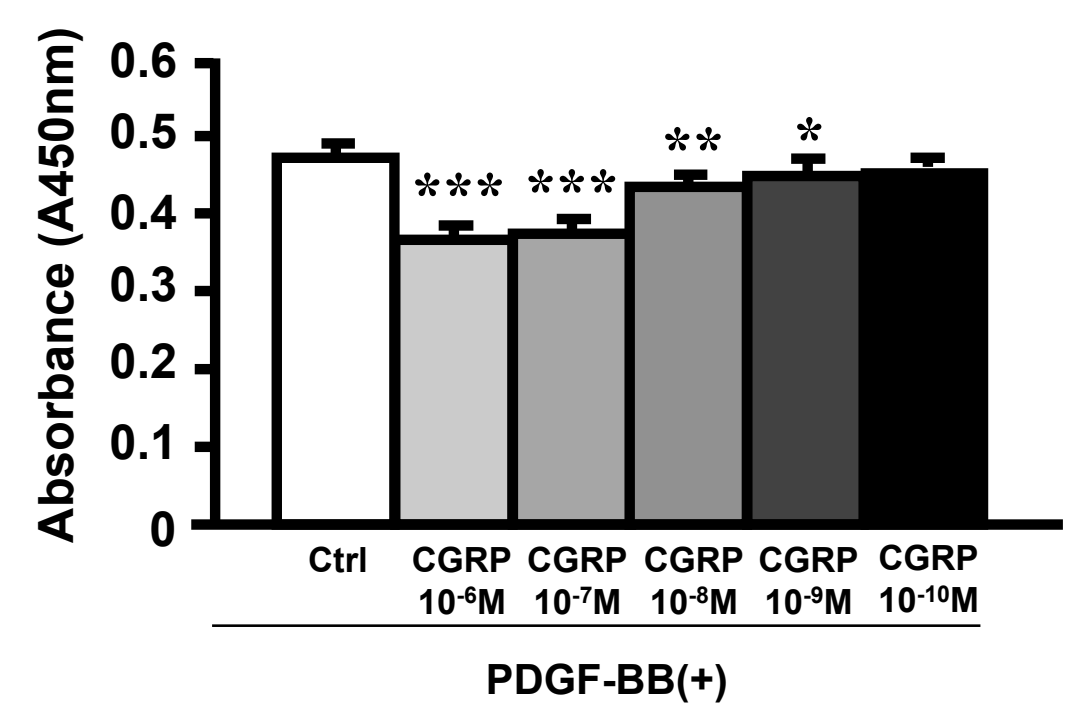

C

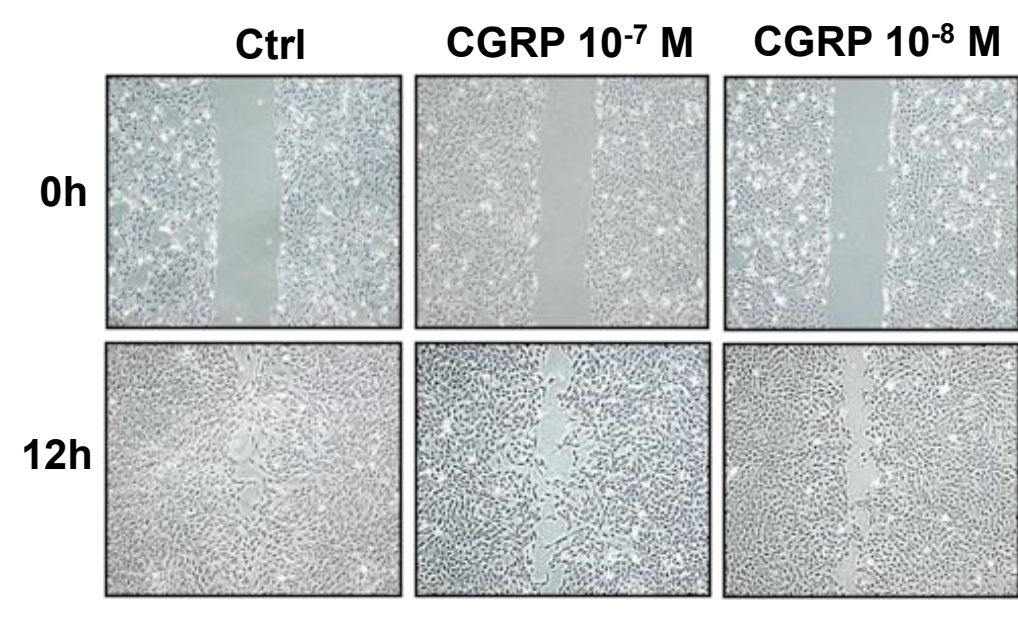

B

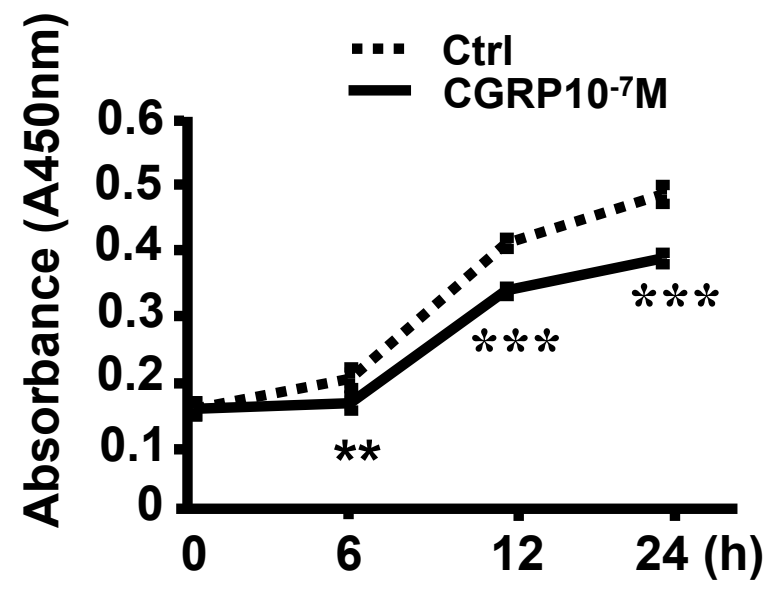

D

E
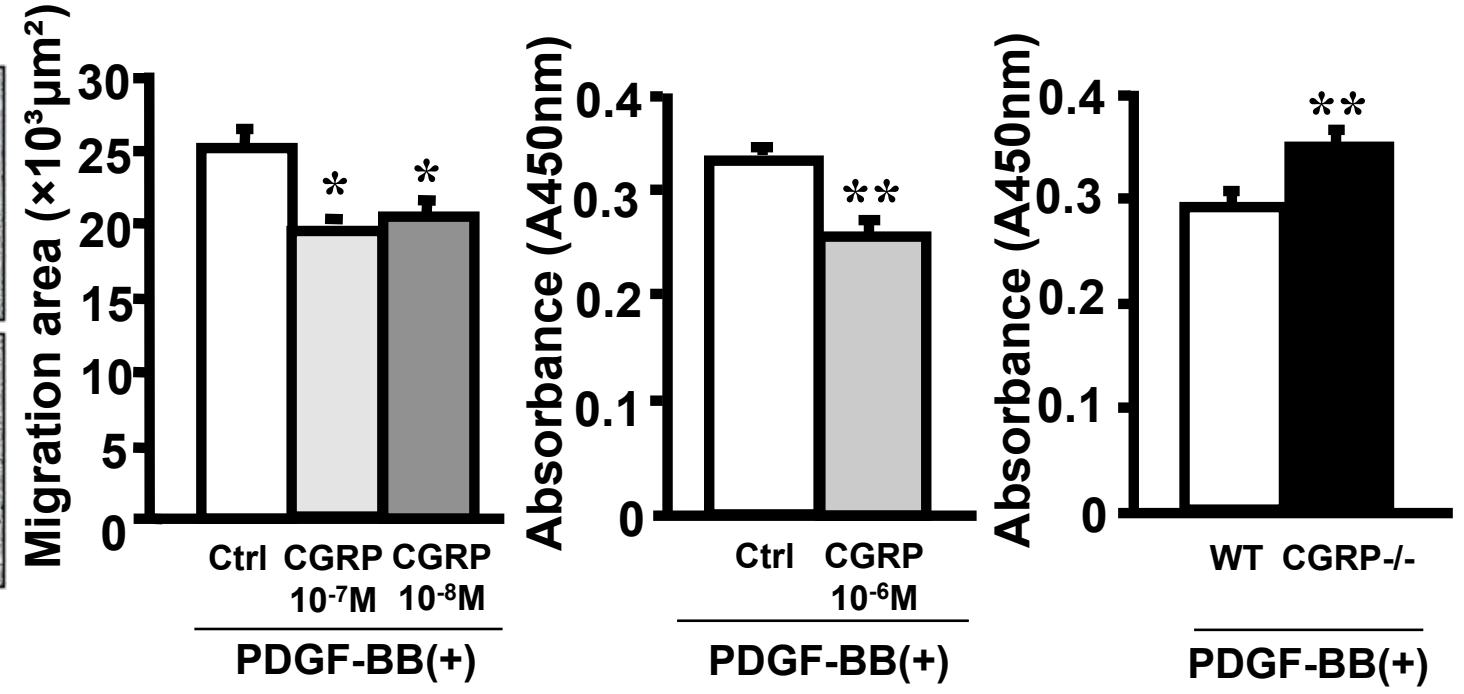

Fig. 6 

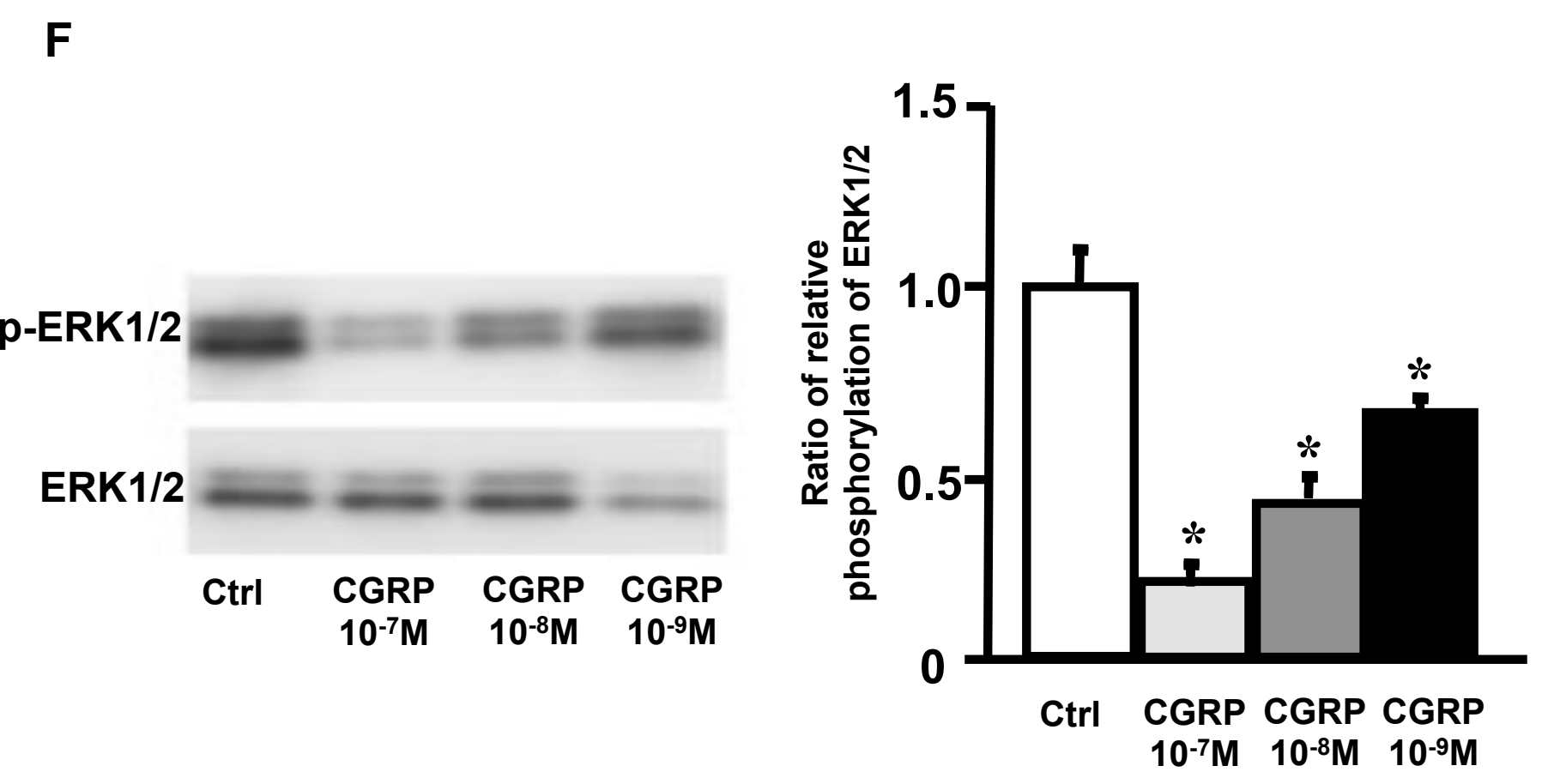

Fig. 6 
A

B $\square$ cGRP-I- Hydralazine(-)

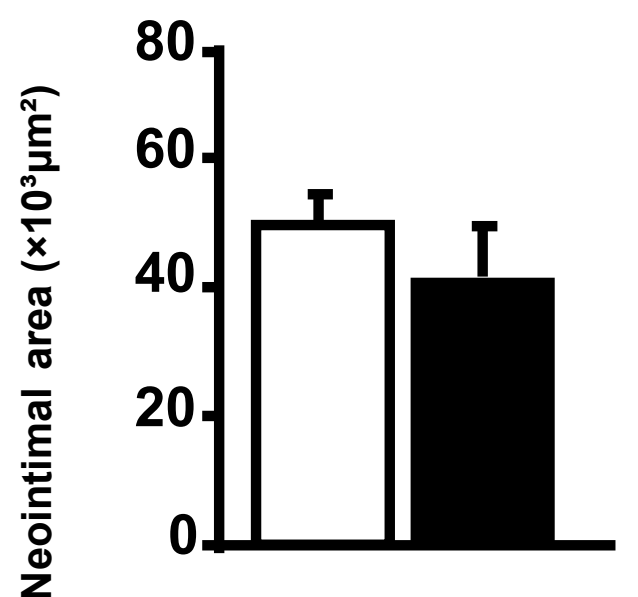

\section{Supplementary Fig 1}

Blood pressure depression did not have an effect on the neointimal formation in CGRP-/-. CGRP-/- underwent wire-induced vascular injury, and 2 days after the operation, some were administered hydralazine (Sigma) in drinking water ( $5 \mathrm{mg} / \mathrm{kg} /$ day). After 4 weeks, systolic blood pressure (SBP), measured by the tail-cuff method (Model MK-2000ST, Muromachi Kikai Co., Japan), was significantly reduced in the hydralazine-treated group (A). On the other hand, the neointimal formation was not different between the hydralazine-treated and non-treated groups (B). Bars depict means \pm SE ( $n=8$ for each); ${ }^{*} P<0.05$. 
A

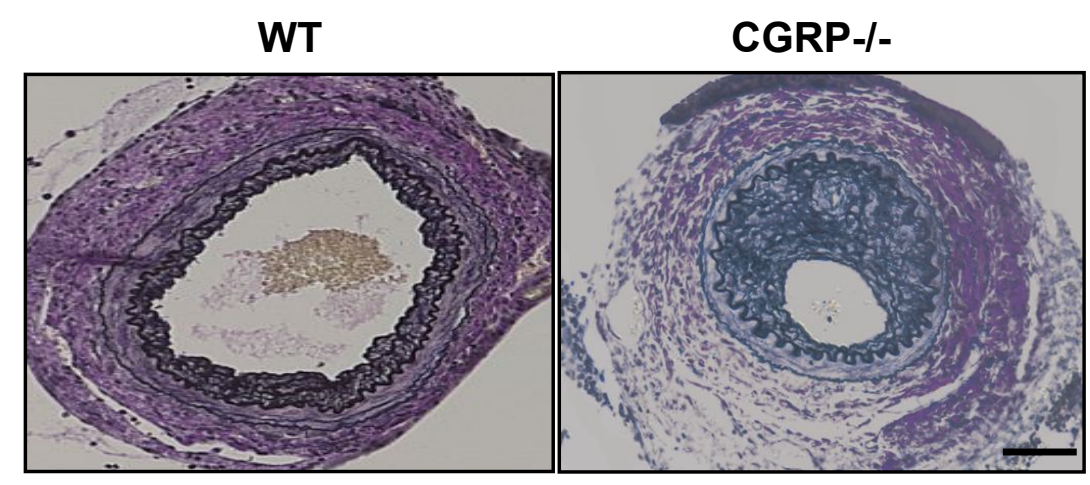

B

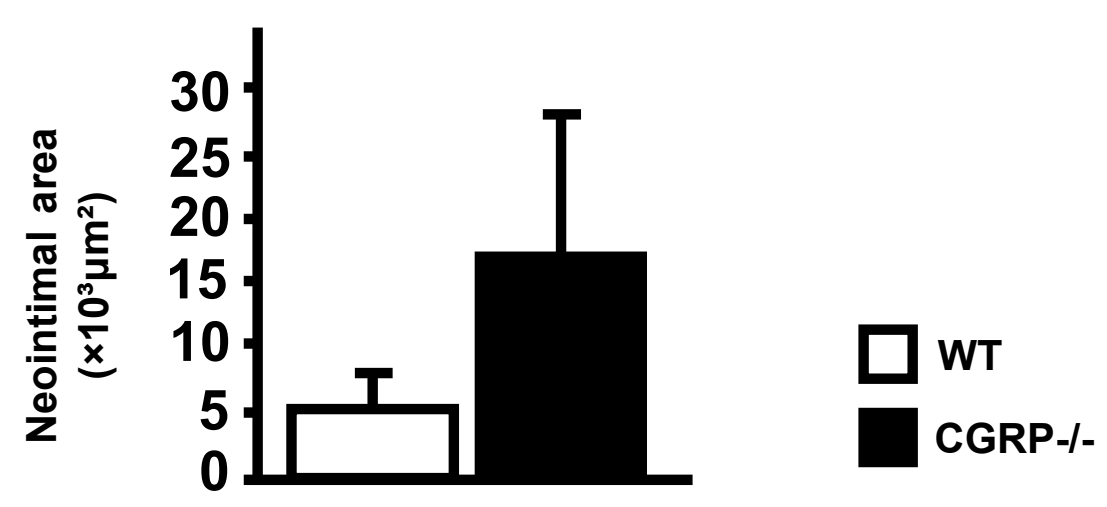

\section{Supplementary Fig 2}

Changes in neointimal hyperplasia in the cuff-induced vascular injury model. A, Sections stained with EVG to evaluate neointima formation of WT and CGRP-/- mice at 28 days after cuff-induced vascular injury. Bar $=100 \mu \mathrm{m}$. $B$, Bar graphs showing the neointimal area. Bars depict means $\pm S E$ ( $n=8$ for each). 


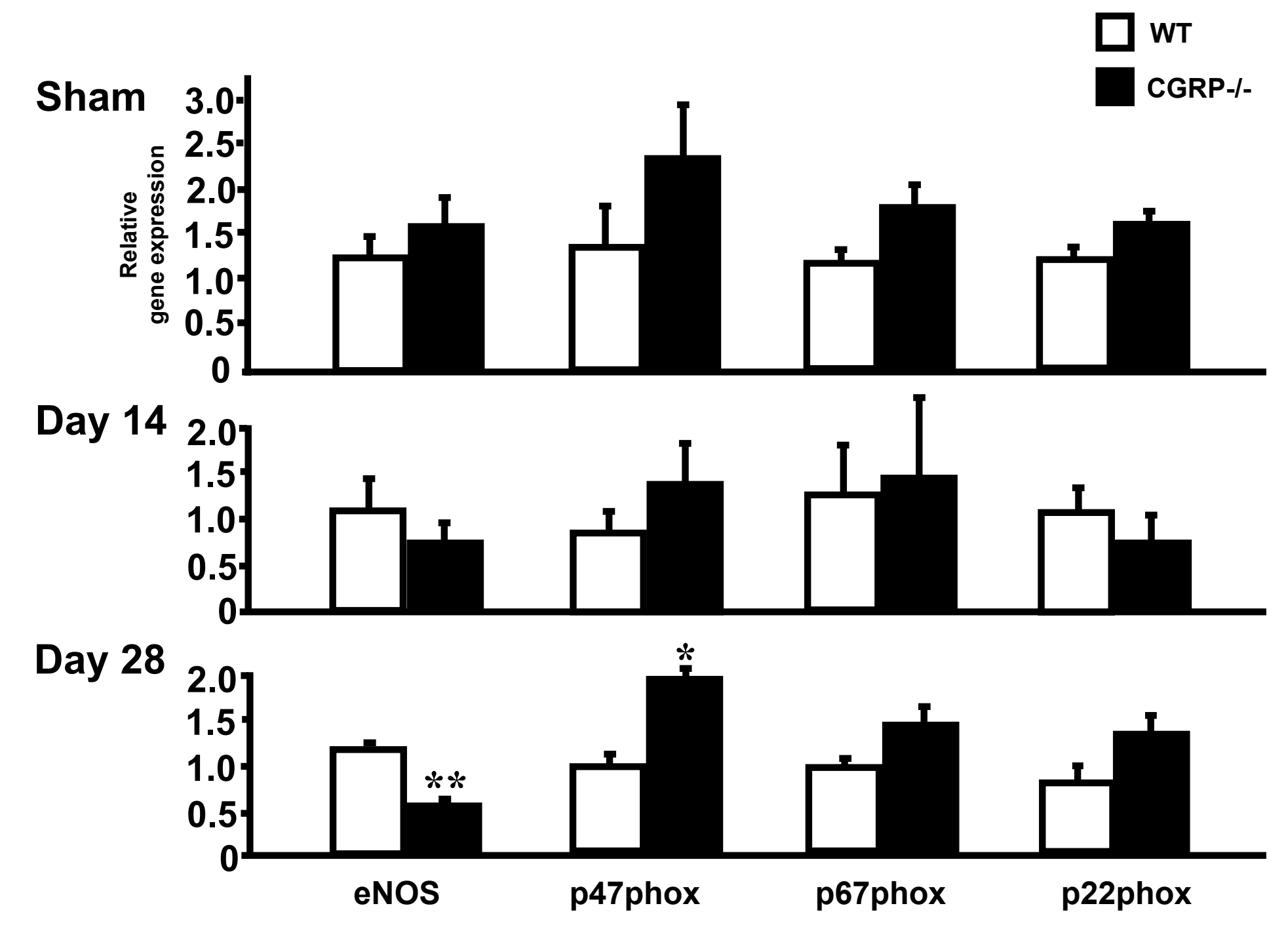

Supplementary Fig. 3

Changes in expression of oxidative stress-related genes before and after wire injury. Quantitative real-time PCR analysis of the indicated oxidative stress-related genes in sham, day 14 , and day 28 specimens after wire injury. Bars depict means $\pm S E(n=5$ for each); ${ }^{* *} \mathrm{P}<0.01,{ }^{*} \mathrm{P}<0.05$ vs. WT. 